\title{
СУИЦИДАМЬНОЕ ПОВЕДЕНИЕ: ГЕНЕТИЧЕСКИЙ АСПЕКТ ГЕНДЕРНОГО ПАРАДОКСА
}

\author{
В.А. Козлов, С.П. Сапожников, А.В. Голенков \\ ФГБОУ ВО «Чувашский государственный университет имени И.Н. УАьянова», г. Чебоксары, Россия
}

SUICIDAL BEHAVIOR: THE GENETIC ASPECT OF THE GENDER PARADOX

V.A. Kozlov, S.P. Sapozhnikov,

I.N. Ulyanov Chuvash State University, Cheboksary, Russia

A.V. Golenkov

Информация об авторах:

Козцов Вадим Авенирович - доктор биологических наук, кандидат медицинских наук, профессор (SPIN-код: 1915-5416; Researcher ID: I-5709-2014; ORCID iD 0000-0001-7488-1240; Scopus Author ID:_56712299500). Mecto работы и должность: профессор кафедры медицинской биологии с курсом микробиологии и вирусологии, ФГБОУ ВО «Чувашский государственный университет им. И.Н. УАьянова». Адрес: Россия, г. Чебоксары, Московский проспект, 45. Темефон: +7 (903) 379-56-44, эмектронный адрес: pooh12@уandex.ru

Сапожников Сергей Павцович - доктор медицинских наук, профессор (SPIN-код: 6985-9660; Researcher ID: C-5335-2019; ORCID iD: 0000-0003-0967-7192). Место работы и должность: заведующий кафедрой медицинской биологии с курсом микробиологии и вирусологии ФГБОУ ВО “Чувашский государственный университет им. И.Н. УАьянова". Адрес: Россия, г. Чебоксары, Московский проспект, 45. Телефон: +7 (965) 689-54-45, электронный адрес: adaptagon@mail.ru

Голенков Андрей Васицьевич - доктор медицинских наук, профессор (SPIN-код: 7936-1466; Researcher ID: C-4806-2019; ORCID iD: 0000-0002-3799-0736; Scopus Author ID: 36096702300). Место работы и должность: заведующий кафедрой психиатрии, медицинской психомогии и неврологии ФГБОУ ВО «Чувашский государственный университет им. И.Н. УАьянова". Адрес: Россия, г. Чебоксары, ул. Пирогова, 6. Телефон: +7 (905) 197-35-25, эмектронный адрес: golenkovav@inbox.ru

Information about the authors:

Kozlov Vadim Avenirovich - MD, PhD, Professor (SPIN-code: 1915-5416; Researcher ID: I-5709-2014; ORCID iD: 0000-0001-7488-1240; Scopus Author ID: 56712299500). Place of work and position: Professor of the Department of Medical Biology with a course in Microbiology and Virology, I.N. Ulyanov Chuvash State University. Address: Russia, Cheboksary, 45 Moskovsky prospect. Phone: +7 (903) 379-56-44, email: pooh12@yandex.ru

Sapozhnikov Sergey Pavlovich - MD, PhD, Professor (SPIN-code: 6985-9660; Researcher ID: C-5335-2019; ORCID iD: 0000-0003-0967-7192). Place of work and position: Head of the Department of Medical Biology with a course in Microbiology and Virology, I.N. Ulyanov Chuvash State University. Address: Russia, Cheboksary, 45 Moskovsky prospect. Phone: +7 (965) 689-54-45, e-mail: adaptagon@mail.ru

Golenkov Andrei Vasilievich - MD, PhD, Professor (SPIN-code: 7936-1466; Researcher ID: C-4806-2019; ORCID iD: 0000-0002-3799-0736; Scopus Author ID: 36096702300). Place of work and position: Head of the Department of Psychiatrics, Medical Psychology and Neurology, I.N. Ulyanov Chuvash State University. Address: Russia, Cheboksary, 6 Pirogov Str. Phone: +7 (905) 197-35-25, email: golenkovav@inbox.ru

Цель работы - систематизация и интерпретация находящихся в свободном доступе, разрозненных, ранее установленных данных об ассоциации частот совершаемых суицидов с гендерными (половыми) генетическими различиями, конечным итогом которой является формирование представления о различных паттернах генов, формирующих суицидальный фенотип у мужчин и женщин как минимум двумя разными генетически реализуемыми путями. В статье рассмотрены вопросы биологических причин формирования суицидального фенотипа как следствие генетической программы, реализуемой в результате взаимодействия паттерна полиморфных генов. В результате расчёта коэффициента гендерной суицидальности (КГС - частное от деления относительных показателей частот суицидов у мужчин на частоты суицидов у женщин, полученные по данным ВОЗ по состоянию на 2019) сделан вывод, что величина КГС в целом постоянна и не зависит от климатических, географических, экономических, социальных и прочих внешних факторов. То есть, определена генным фондом человечества. При анализе данных литературы, взятых в базе pubmed.ncbi.nlm.nih.gov, примерно за 20-летний период, о генетических различиях суицидентов мужчин и женщин исключали работы, в которых суициды или суицидальные попытки совершались на фоне тяжёлых психических расстройств, либо отдель- 
ных аддикций, или в связи с актами насилия. Собранные сведения позволили свести воедино два паттерна генов, формирующих суицидальный фенотип у мужчин и женщин соответственно. Большая часть генов, ассоциируемых с суицидами у мужчин преимущественно локализована на коротком плече хромосомы X, и хромосоме 22 , а также на хромосомах $1,2,5,7,11,19$. Кроме того, у мужчин суициды ассоциированы с возрастной аберрантной потерей хромосомы Ү клетками крови. У женщин с суицидами ассоциированы гены, локализованные на хромосомах 7, 10, 11, 17 и ген HTR2C локус Хq23. Так же должен существовать третий не связанный с полом паттерн ассоциируемых с суицидом генов. Сделаны выboды, что 1) существуют полоспецифичные паттерны генетических полиморфизмов, совокупная активность которых завершается суицидом в определённые возрастные периоды, что определяет дожитие их носителей до возраста совершения суицида; 2) носительство таких паттернов в геноме может быть расценено как мультифакториальное состояние, исходом которого является смерть в результате совершения суицида, а не функционального возрастного истощения каких-либо систем органов.

Ключевые слова: суицид, гендерный парадокс, паттерны ассоциированных с суицидом генов, коэффициент гендерной суицидальности

\section{Suum cuique Цицерон}

Несмотря на навязываемые идеи гендерного равенства, вплоть до полного отрицания биологии, в популяции людей существуют явления, доказывающие абсолютный примат биологии над социальными надстройками. Одно из таких явлений - так называемый гендерный парадокс [1], заключающийся в том, что женщины чаще говорят о своём вероятном суициде, чем реально совершают его, тогда как мужчины чаще молчат о планируемом самоубийстве и совершают его в разы чаще, чем женщины [2]. Правило настолько абсолютное, что это соотношение сохраняется во всех странах и на всех континентах вне зависимости от социального устройства, конфессиональной принадлежности, экономического благополучия как государств, так и отдельных индивидуумов, возможных локальных особенностей статистического учёта, наблюдающиеся в некоторых странах [3]. Деление по возрасту, географическому положению, социальноэкономическому благополучию влияет только на величину этого соотношения, но не на сам факт значительного преобладания числа суицидов среди мужчин над числом суицидов среди женщин $[3,4]$. Конечно, такие факторы как: религиозность, социально-экономическое благополучие, употребление алкоголя, наркотиков, число разводов, политика и т.д., - имеют связь с количеством суицидов, но ни один из них не является абсолютным [5].

Сексуальная ориентация, по-видимому, также не имеет существенного значения, поскольку среди трансгендеров, которые могут быть и гетеросексуалами, и гомосексуалами, и бисексуалами, по данным метаанализа 47 исследований, осуществлённых за период с 1997 по 2007 гг., частота суицидов была в 20-22 раза больше, чем у населения в целом. Но и у трансгендеров число завершённых суицидов выше среди лиц мужского пола, чем среди лиц женского пола $[6,7]$. Тем не
Suum cuique Cicero

Despite the imposed ideas of gender equality, up to the complete denial of biology, there are phenomena in the human population that prove the absolute primacy of biology over social superstructures. One of these phenomena is the so-called gender paradox [1], which consists in the fact that women are more likely to talk about their probable suicide rather than actually commit it, while men are more often silent about planned suicide and commit it many times more often than women [2]. The rule is so absolute that this ratio is maintained throughout all countries and on all continents, regardless of the social structure, confessional affiliation, economic well-being of both states and individuals, possible local features of statistical accounting observed in some countries [3]. Division by age, geographic location, socio-economic well-being affects only the value of this ratio, but not the very fact of a significant predominance of the number of suicides among men over the number of suicides among women [3, 4]. Of course, such factors as religion, socioeconomic well-being, alcohol, drug use, the number of divorces, politics, etc., are connected with the number of suicides, but none of them is absolute [ five].

Sexual orientation also does not seem to matter, since among transgender people, who can be heterosexual, homosexual, or bisexual, according to a meta-analysis of 47 studies carried out from 1997 to 2007, the frequency of suicides was 20-22 times more than the general population. But even among transgender people, the number of completed suicides is higher among males than among females [6, 7]. However, consideration of the relationship between transgender people and suicide is not the subject of this work. 
менее, рассмотрение связи трансгендерности с суицидами не является предметом данной работы.

Ниже мы приводим статистические доказательства высказанного предположения (табл. 1). В таблице представлены относительные данные смертности мужчин и женщин на 100000 населения по данным ВОЗ по состоянию на 2019 г. [8], несмотря на то, что ВОЗ осуществляет мониторинг данных о суицидах из 137 стран, в цитируемой таблице было представлено только 80 государств. На основе этих данных нами вычислен коэффициент гендерности суицидов как отношение относительного числа суицидов мужчин на 100000 населения в данной стране к относительному числу суицидов женщин на 100000 населения.

Для лучшего восприятия часть этих данных представлена на картограмме. Страны, данные по которым на сайте ВО3 отсутствуют (в основном африканские), выделены серым цветом. Как видим, коэффициент гендерности во всех странах, кроме Гренады, значительно больше 1,0. Гистограмма распределения этих коэффициентов отличается от нормального распределения.

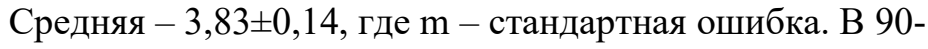
й перцентиль входят значения выше 5,41, в 10-й - менее 2,1. Нижний квартиль 2,67, верхний - 4,52, квартильный размах $-1,85$. Коэффициент вариации $-48,29$. Коэффициент вариации по относительным числам суицидов для мужчин - он равен 90,66, для женщин он меньше - 77,91. При отсечении крайних значений $1,8<$ коэффициент гендерности $>7,0$, коэффициенты вариации практически не меняются. То есть, в целом коэффициент гендерности суицидов устойчив. В верхний квартиль входят всего 17 государств, в нижний -45 . Самые высокие значения (более 7,0) получились для шести государств. Таким образом, из приведённых данных следует, что высказанная нами вводная сентенция имеет статистическое подтверждение.

Представленные в таблице 180 стран действительно значительно различаются по многим параметрам, но предложенный коэффициент остаётся очень стабильным даже при таком большом количестве суицидов, как в Лесото. Более того, различия коэффициентов вариации между женской и мужской выборкой свидетельствуют, что увеличение или снижение гендерного коэффициента суицидов преимущественно происходит за счёт увеличения или снижения числа самоубийств у мужчин. Небольшой гендерный коэффициент наблюдается в странах, где отмечается общее низкое число суицидов [9], как правило, в связи с небольшим количеством населения в государстве. Если эти отношения проследить по другим годам, общая картина не изменится.
Below we provide statistical evidence of this assumption (Table 1). The table presents the relative mortality data for men and women per 100,000 population according to WHO data as of 2019 [8], despite the fact that WHO monitors suicide data from 137 countries, only 80 countries were represented in the cited table. Based on these data, we calculated the gender ratio of suicides as the ratio of the relative number of suicides of men per 100,000 population in a given country to the relative number of suicides of women per 100,000 population.

For better perception, some of this data is presented on the cartogram. Countries for which data are not available on the WHO website (mostly African) are highlighted in gray. As you can see, the gender coefficient in all countries, except for Grenada, is significantly higher than 1.0. The histogram of the distribution of these coefficients differs from the normal distribution. The Median is $3.83 \pm$ 0.14 , where $m$ is the standard error. The 90th percentile includes values above 5.41 , the 10 th includes indexes that are less than 2.1. The lower quartile is 2.67 , the upper quartile is 4.52 , and the quartile range is 1.85 . The coefficient of variation is 48.29 . The coefficient of variation for the relative numbers of suicides for men is 90.66 , for women it is less than 77.91. When cutting off extreme values 1.8 <gender coefficient> 7.0, the coefficients of variation practically do not change. That is, in general, the gender ratio of suicides is stable. The upper quartile includes only 17 states, the lower encompasses 45 . The highest values (over 7.0) were obtained for six states. Thus, it follows from the data presented that our introductory maxim has been statistically confirmed.

The 80 countries presented in Table 1 do differ significantly in many parameters, but the proposed ratio remains very stable even with such a large number of suicides as in Lesotho. Moreover, the differences in the coefficients of variation between the female and male sample indicate that an increase or decrease in the gender coefficient of suicides is mainly due to an increase or decrease in the number of suicides among men. A small gender coefficient is observed in countries where there is an overall low number of suicides [9], usually due to the small number of population in the state. If this relationship is traced back to other years, the overall picture will not change. 
Таблица / Table 1

Число суицидов на 100000 населения по данным ВОЗ (2019), и коэффициент гендерности суицидов [5] The number of suicides per 100,000 population according to WHO (2019), and gender ratio of suicides [5]

\begin{tabular}{|c|c|c|c|}
\hline $\begin{array}{l}\text { Государство } \\
\text { State }\end{array}$ & $\pi$ & 9 & \begin{tabular}{|c} 
Коэффициент \\
гендерности \\
суицидов \\
Gender \\
suicide rate
\end{tabular} \\
\hline Австралия / Australia & 17,0 & 5,6 & 3,0 \\
\hline Австрия / Austria & 16,6 & 4,6 & 3,6 \\
\hline Азербайджан / Azerbaijan & 6,6 & 1,5 & 4,4 \\
\hline Албания / Albania & 5,3 & 2,2 & 2,4 \\
\hline Ангола / Angola & 21,7 & 4,7 & 4,6 \\
\hline Аргентина / Argentina & 13,5 & 3,3 & 4,1 \\
\hline Армения / Armenia & 4,9 & 1,0 & 4,9 \\
\hline Афганистан / Afghanistan & 6,2 & 5,7 & 1,1 \\
\hline Багамы / Bahamas & 5,8 & 1,2 & 4,8 \\
\hline Бангладеш / Bangladesh & 6,0 & 1,7 & 3,5 \\
\hline Бахрейн / Bahrain & 9,9 & 2,3 & 4,3 \\
\hline Беларусь / Belarus & 30,1 & 5,3 & 5,7 \\
\hline Белиз / Belize & 13,6 & 1,8 & 7,6 \\
\hline Бельгия / Belgium & 19,6 & 8,4 & 2,3 \\
\hline Бенин / Benin & 20,3 & 6,1 & 3,3 \\
\hline Болгария / Bulgaria & 10,6 & 2,9 & 3,7 \\
\hline Боливия / Bolivia & 9,5 & 4,2 & 2,3 \\
\hline $\begin{array}{l}\text { Босния и Герцеговина } \\
\text { Bosnia and Herzegovina }\end{array}$ & 13,5 & 3,4 & 4,0 \\
\hline Ботсвана / Botswana & 35,5 & 7,8 & 4,6 \\
\hline Бразилия / Brazil & 35,5 & 7,8 & 4,6 \\
\hline Бруней / Brunei & 4,2 & 0,8 & 5,3 \\
\hline $\begin{array}{l}\text { Объединенные Арабские } \\
\text { Эмираты } \\
\text { United Arab Emirates } \\
\end{array}$ & 6,3 & 2,6 & 2,4 \\
\hline $\begin{array}{l}\text { Буркина Фасо } \\
\text { Burkina Faso } \\
\end{array}$ & 24,5 & 6,5 & 3,8 \\
\hline Бурунди / Burundi & 18,9 & 6,4 & 3,0 \\
\hline Бутан / Bhutan & 6,8 & 3,1 & 2,2 \\
\hline Вануату / Vanuatu & 33,1 & 9,0 & 3,7 \\
\hline $\begin{array}{l}\text { Великобритания } \\
\text { Great Britain }\end{array}$ & 10,4 & 3,4 & 3,1 \\
\hline Венгрия / Hungary & 19,1 & 5,5 & 3,5 \\
\hline Венесуэла / Venezuela & 3,7 & 0,7 & 5,3 \\
\hline $\begin{array}{l}\text { Восточный Тимор } \\
\text { East Timor }\end{array}$ & 6,7 & 2,4 & 2,8 \\
\hline Вьетнам / Vietnam & 10,6 & 4,2 & 2,5 \\
\hline Габон / Gabon & 23,3 & 3,8 & 6,1 \\
\hline Гаити / Haiti & 14,9 & 8,0 & 1,9 \\
\hline Гамбия / Gambia & 13,3 & 6,2 & 2,1 \\
\hline Гана / Ghana & 20,2 & 1,8 & 11,2 \\
\hline $\begin{array}{l}\text { Гватемала } \\
\text { Guatemala }\end{array}$ & 10,3 & 2,5 & 4,1 \\
\hline Гвиана / Guiana & 65,0 & 17,0 & 3,8 \\
\hline Гвинея / Guinea & 10,3 & 2,5 & 4,1 \\
\hline $\begin{array}{l}\text { Гвинея Бисау } \\
\text { Guinea Bissau }\end{array}$ & 19,8 & 6,7 & 3,0 \\
\hline
\end{tabular}

\begin{tabular}{|c|c|c|c|}
\hline $\begin{array}{l}\text { Государство } \\
\text { State }\end{array}$ & 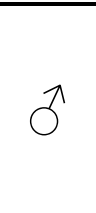 & $\uparrow$ & $\begin{array}{c}\text { Коэффициент } \\
\text { гендерности } \\
\text { суицидов } \\
\text { Gender } \\
\text { suicide rate }\end{array}$ \\
\hline Мадагаскар / Madagascar & 13,3 & 5,4 & 2,5 \\
\hline Малави / Malawi & 20,0 & 3,3 & 6,1 \\
\hline Малайзия / Malaysia & 9,0 & 2,4 & 3,8 \\
\hline Мали / Mali & 10,5 & 5,7 & 1,8 \\
\hline Мальдивы / Maldives & 4,1 & 0,9 & 4,6 \\
\hline Мальта / Malta & 8,4 & 2,3 & 3,7 \\
\hline Марокко / Morocco & 10,1 & 4,7 & 2,1 \\
\hline Мексика / Mexico & 8,7 & 2,2 & 4,0 \\
\hline Микронезия / Micronesia & 44,3 & 13,2 & 3,4 \\
\hline Мозамбик / Mozambique & 42,6 & 8,9 & 4,8 \\
\hline Монголия / Mongolia & 31,1 & 5,6 & 5,6 \\
\hline Монтенегро / Montenegro & 25,4 & 7,9 & 3,2 \\
\hline Мьянма / Myanmar & 5,1 & 1,1 & 4,6 \\
\hline Намибия / Namibia & 24,9 & 4,4 & 5,7 \\
\hline Непал / Nepal & 18,6 & 2,9 & 6,4 \\
\hline Нигер / Niger & 14,1 & 6,4 & 2,2 \\
\hline Нигерия / Nigeria & 10,1 & 3,8 & 2,7 \\
\hline $\begin{array}{l}\text { Народная Демократиче- } \\
\text { ская Республика Лаос } \\
\text { People's Democratic } \\
\text { Republic of Laos } \\
\end{array}$ & 8,6 & 3,5 & 2,5 \\
\hline Нидерланды Netherlands & 12,5 & 6,1 & 2,0 \\
\hline Никарагуа / Nicaragua & 7,8 & 1,9 & 4,1 \\
\hline Норвегия / Norway & 13,4 & 6,3 & 2,1 \\
\hline $\begin{array}{l}\text { Объединенная } \\
\text { Республика Танзания } \\
\text { United Republic of Tanzani }\end{array}$ & 13,5 & 3,7 & 3,6 \\
\hline $\begin{array}{l}\text { Новая Зеландия } \\
\text { New Zealand } \\
\end{array}$ & 15,4 & 5,4 & 2,9 \\
\hline Оман / Oman & 6,4 & 1,1 & 5,8 \\
\hline Пакистан / Pakistan & 14,6 & 4,8 & 3,0 \\
\hline Панама / Panama & 4,8 & 1,0 & 4,8 \\
\hline $\begin{array}{l}\text { Папуа и Новая Гвинея } \\
\text { Papua and New Guinea }\end{array}$ & 5,2 & 1,9 & 2,7 \\
\hline Парагвай / Paraguay & 9,0 & 3,3 & 2,7 \\
\hline Перу / Peru & 4,1 & 1,4 & 2,9 \\
\hline $\begin{array}{l}\text { Республика Kopeя } \\
\text { Republic of Korea }\end{array}$ & 29,7 & 13,4 & 2,2 \\
\hline Польша / Poland & 16,5 & 2,4 & 6,9 \\
\hline Португалия / Portugal & 11,6 & 3,5 & 3,3 \\
\hline Россия / Russia & 38,2 & 7,2 & 5,3 \\
\hline Руанда / Rwanda & 14,8 & 5,0 & 3,0 \\
\hline Румыния / Romania & 12,6 & 2,4 & 5,3 \\
\hline Сальвадор / El Salvador & 11,1 & 2,1 & 5,3 \\
\hline Самоа / Samoa & 20,9 & 7,8 & 2,7 \\
\hline Санта Лючия / Santa Lucia & 12,5 & 1,5 & 8,3 \\
\hline
\end{tabular}




\begin{tabular}{|c|c|c|c|}
\hline $\begin{array}{c}\text { Государство } \\
\text { State }\end{array}$ & $\delta$ & 9 & $\begin{array}{c}\text { Коэффициент } \\
\text { гендерности } \\
\text { суицидов } \\
\text { Gender } \\
\text { suicide rate } \\
\end{array}$ \\
\hline $\begin{array}{l}\text { Германия } \\
\text { Deutschland }\end{array}$ & 12,8 & 3,9 & 3,3 \\
\hline $\begin{array}{l}\text { Гондурас } \\
\text { Honduras }\end{array}$ & 4,4 & 1,0 & 4,4 \\
\hline $\begin{array}{l}\text { Гренада } \\
\text { Grenada }\end{array}$ & 0,5 & 0,7 & 0,7 \\
\hline Греция / Greece & 5,9 & 1,5 & 3,9 \\
\hline Грузия / Georgia & 14,0 & 2,2 & 6,4 \\
\hline $\begin{array}{l}\text { Демократическая } \\
\text { Республика Корея } \\
\text { Democratic Party } \\
\text { Republic of Korea }\end{array}$ & 10,6 & 6,3 & 1,7 \\
\hline Дания / Denmark & 11,1 & 4,2 & 2,6 \\
\hline $\begin{array}{l}\text { Демократическая } \\
\text { Республика Конго } \\
\text { Democratic Party } \\
\text { Republic of the Congo }\end{array}$ & 20,7 & 5,0 & 4,1 \\
\hline Джибути / Djibouti & 16,3 & 7,6 & 2,1 \\
\hline $\begin{array}{l}\text { Доминиканская } \\
\text { Республика } \\
\text { Dominican Republic }\end{array}$ & 8,5 & 1,9 & 4,5 \\
\hline Египет / Egypt & 4,7 & 2,2 & 2,1 \\
\hline $\begin{array}{l}\text { Замбия } \\
\text { Zambia }\end{array}$ & 25,7 & 5,3 & 4,8 \\
\hline Зимбабве / Zimbabwe & 37,8 & 13,5 & 2,8 \\
\hline Израиль / Israel & 8,3 & 2,1 & 4,0 \\
\hline Индия / India & 14,7 & 11,1 & 1,3 \\
\hline Индонезия / Indonesia & 4,0 & 1,2 & 3,3 \\
\hline Иордан / Jordan & 3,0 & 0,9 & 3,3 \\
\hline Ирак / Iraq & 7,3 & 2,4 & 3,0 \\
\hline Иран / Iran & 7,5 & 2,8 & 2,7 \\
\hline Ирландия / Irish & 14,3 & 3,6 & 4,0 \\
\hline Исландия / Iceland & 18,7 & 3,5 & 5,3 \\
\hline Испания / Spain & 7,9 & 2,8 & 2,8 \\
\hline Италия / Italy & 6,7 & 2,1 & 3,2 \\
\hline Йемен / Yemen & 9,0 & 5,3 & 1,7 \\
\hline Кабо Верде / Cape Verde & 27,4 & 5,1 & 5,4 \\
\hline Казахстан / Kazakhstan & 30,9 & 6,9 & 4,5 \\
\hline Камбоджа / Cambodia & 25,2 & 7,6 & 3,3 \\
\hline Камерун / Cameroon & 25,2 & 7,6 & 3,3 \\
\hline Канада / Canada & 15,3 & 5,4 & 2,8 \\
\hline Катар / Qatar & 5,7 & 1,7 & 3,4 \\
\hline Кения / Kenya & 18,1 & 5,3 & 3,4 \\
\hline Кипр / Cyprus & 5,3 & 1,1 & 4,8 \\
\hline Киргизстан / Kyrgyzstan & 13,5 & 3,5 & 3,9 \\
\hline Кирибати / Kiribati & 53,6 & 9,5 & 5,6 \\
\hline
\end{tabular}

\begin{tabular}{|c|c|c|c|}
\hline $\begin{array}{c}\text { Государство } \\
\text { State }\end{array}$ & $\delta$ & $q$ & $\begin{array}{c}\text { Коэффициент } \\
\text { гендерности } \\
\text { суицидов } \\
\text { Gender } \\
\text { suicide rate } \\
\end{array}$ \\
\hline $\begin{array}{l}\text { Республика Молдова } \\
\text { Republic of Moldova }\end{array}$ & 22,1 & 3,3 & 6,7 \\
\hline $\begin{array}{l}\text { Сан-Томе и Принсипи } \\
\text { Sao Tome and Principe }\end{array}$ & 3,3 & 1,2 & 2,8 \\
\hline $\begin{array}{l}\text { Саудовская Аравия } \\
\text { Saudi Arabia }\end{array}$ & 7,8 & 1,9 & 4,1 \\
\hline $\begin{array}{l}\text { Северная Македония } \\
\text { North Macedonia }\end{array}$ & 11,0 & 3,5 & 3,1 \\
\hline Сейшелы / Seychelles & 14,0 & 1,3 & 10,8 \\
\hline Сенегал / Senegal & 18,5 & 5,2 & 3,6 \\
\hline $\begin{array}{l}\text { Сент Винсент } \\
\text { и Гренадины } \\
\text { St. Vincent and } \\
\text { The Grenadines } \\
\end{array}$ & 1,3 & 0,7 & 1,9 \\
\hline Сербия / Serbia & 12,2 & 3,9 & 3,1 \\
\hline Сингапур / Singapore & 12,7 & 6,4 & 2,0 \\
\hline Словакия / Slovakia & 16,7 & 2,6 & 6,4 \\
\hline $\begin{array}{l}\text { Сирийская Арабская } \\
\text { Республика } \\
\text { Syrian Arab Republic }\end{array}$ & 3,5 & 0,8 & 4,4 \\
\hline Словения / Slovenia & 22,7 & 5,5 & 4,1 \\
\hline $\begin{array}{l}\text { Соломоновы острова } \\
\text { Solomon Islands }\end{array}$ & 32,2 & 2,4 & 13,4 \\
\hline Сомали / Somalia & 22,8 & 7,1 & 3,2 \\
\hline Судан / Sudan & 6,3 & 3,3 & 1,9 \\
\hline Суринам / Suriname & 41,3 & 11,8 & 3,5 \\
\hline США / USA & 22,4 & 6,8 & 3,3 \\
\hline $\begin{array}{l}\text { Сьерра Леоне } \\
\text { Sierra Leone }\end{array}$ & 14,8 & 8,2 & 1,8 \\
\hline Таджикистан / Tajikistan & 7,4 & 3,4 & 2,2 \\
\hline Таиланд / Thailand & 13,9 & 2,3 & 6,0 \\
\hline Того / Togo & 24,0 & 6,5 & 3,7 \\
\hline Тонга / Tonga & 5,9 & 2,9 & 2,0 \\
\hline $\begin{array}{l}\text { Тринидад и Тобаго } \\
\text { Trinidad and Tobago }\end{array}$ & 13,1 & 3,7 & 3,5 \\
\hline Тунис / Tunisia & 4,6 & 1,8 & 2,6 \\
\hline $\begin{array}{l}\text { Туркменистан } \\
\text { Turkmenistan } \\
\end{array}$ & 9,4 & 2,9 & 3,2 \\
\hline Турция / Turkey & 3,6 & 1,2 & 3,0 \\
\hline Уганда / Uganda & 19,4 & 3,7 & 5,2 \\
\hline Узбекистан / Uzbekistan & 11,8 & 4,9 & 2,4 \\
\hline Украина / Ukraine & 32,7 & 4,7 & 7,0 \\
\hline Уругвай / Uruguay & 31,1 & 7,7 & 4,0 \\
\hline Фиджи / Fiji & 13,1 & 6,0 & 2,2 \\
\hline Филиппины / Philippines & 3,9 & 1,3 & 3,0 \\
\hline Финляндия / Finland & 20,1 & 6,8 & 3,0 \\
\hline Франция / France & 15,2 & 4,5 & 3,4 \\
\hline Хорватия / Croatia & 17,7 & 5,1 & 3,5 \\
\hline
\end{tabular}




\begin{tabular}{|c|c|c|c|}
\hline $\begin{array}{c}\text { Государство } \\
\text { State }\end{array}$ & $\hat{0}$ & $q$ & \begin{tabular}{|c|} 
Коэффициент \\
гендерности \\
суицидов \\
Gender \\
suicide rate
\end{tabular} \\
\hline Китай / China & 8,6 & 4,8 & 1,8 \\
\hline Колумбия / Colombia & 6,0 & 1,7 & 3,5 \\
\hline Коморы / Comores & 11,3 & 5,8 & 1,9 \\
\hline Конго / Congo & 18,3 & 6,1 & 3,0 \\
\hline Коста Рика / Costa Rica & 13,3 & 1,9 & 7,0 \\
\hline Кот-д’Ивуар / Ivory Coast & 25,7 & 5,0 & 5,1 \\
\hline Куба / Cuba & 16,7 & 4,1 & 4,1 \\
\hline Кувейт / Kuwait & 3,8 & 0,7 & 5,4 \\
\hline Латвия / Latvian & 29,0 & 4,6 & 6,3 \\
\hline Лесото / Lesotho & 146,9 & 34,6 & 4,2 \\
\hline Либерия / Liberia & 9,4 & 5,5 & 1,7 \\
\hline Ливан / Lebanon & 3,9 & 1,7 & 2,3 \\
\hline Ливия / Libya & 6,1 & 2,9 & 2,1 \\
\hline Литва / Lithuania & 36,1 & 6,2 & 5,8 \\
\hline $\begin{array}{l}\text { Люксембург } \\
\text { Luxembourg }\end{array}$ & 11,8 & 5,4 & 2,2 \\
\hline Маврикий / Mauritius & 15,0 & 2,5 & 6,0 \\
\hline Мавритания / Mauritania & 7,4 & 3,9 & 1,9 \\
\hline
\end{tabular}

\begin{tabular}{|c|c|c|c|}
\hline $\begin{array}{l}\text { Государство } \\
\text { State }\end{array}$ & 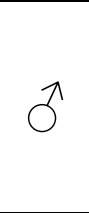 & $q$ & \begin{tabular}{|c} 
Коэффициент \\
гендерности \\
суицидов \\
Gender \\
suicide rate
\end{tabular} \\
\hline $\begin{array}{l}\text { Центральная } \\
\text { Африканская Республика } \\
\text { Central African Republic }\end{array}$ & 39,6 & 9,3 & 4,3 \\
\hline Чад / Chad & 20,2 & 6,9 & 2,9 \\
\hline Чехия / Czech Republic & 15,4 & 3,8 & 4,1 \\
\hline Чили / Chile & 13,4 & 3,0 & 4,5 \\
\hline Швейцария / Switzerland & 14,2 & 5,7 & 2,5 \\
\hline Швеция / Sweden & 16,9 & 7,7 & 2,2 \\
\hline Шри Ланка / Sri Lanka & 20,9 & 6,1 & 3,4 \\
\hline Эквадор / Ecuador & 11,9 & 3,6 & 3,3 \\
\hline $\begin{array}{l}\text { Экваториальная Гвинея } \\
\text { Equatorial Guinea }\end{array}$ & 18,5 & 8,8 & 2,1 \\
\hline Эритрея / Eritrea & 27,2 & 8,3 & 3,3 \\
\hline Эсватини / Eswatini & 78,7 & 6,4 & 12,3 \\
\hline Эстония / Estonia & 20,2 & 4,5 & 4,5 \\
\hline Эфиопия / Ethiopia & 14,2 & 5,2 & 2,7 \\
\hline $\begin{array}{l}\text { Южная Африка } \\
\text { South Africa }\end{array}$ & 37,9 & 9,8 & 3,9 \\
\hline $\begin{array}{l}\text { Южный Судан } \\
\text { South Sudan }\end{array}$ & 10,4 & 3,4 & 3,1 \\
\hline Ямайка / Jamaica & 3,6 & 1,0 & 3,6 \\
\hline Япония / Japan & 17,5 & 6,9 & 2,5 \\
\hline
\end{tabular}

Картограмма коэффициента гендерности суицидов в 2019 г.

(Относительное число суицидов мужчин: Относительное число суицидов женщин Картограмма построена по материалам Global Health Observatory data repository [8]) 2019 Suicide Gender Ratio Cartogram

(Relative number of suicides of men vs. relative number of suicides of women The cartogram is based on the materials of the Global Health Observatory data repository [8])

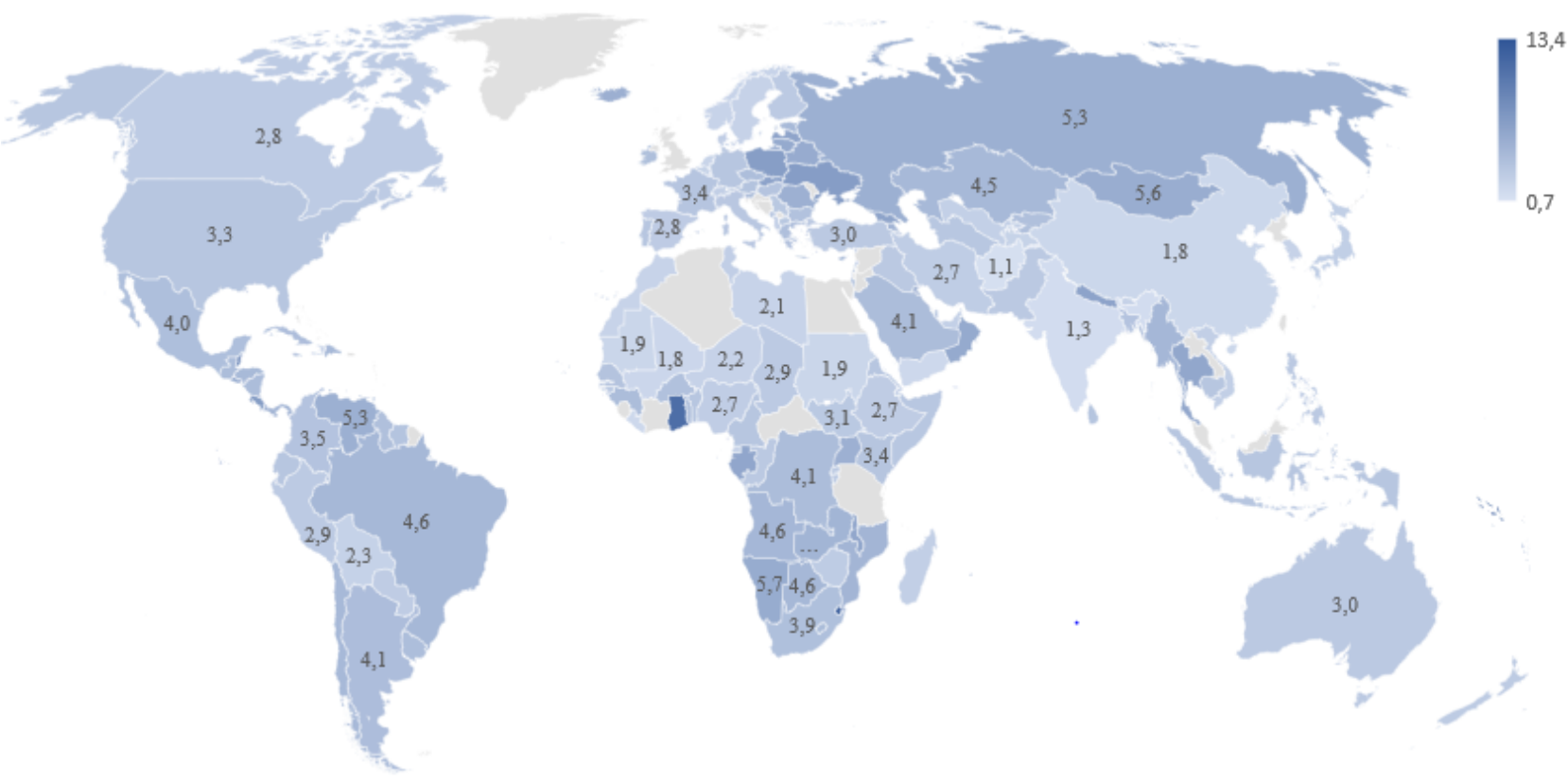


При анализе картограммы складывается впечатление, что коэффициент гендерности в целом уменьшается ближе к тропической зоне, напротив, чем ближе к арктической и антарктической зонам, тем он больше. Но это правило прослеживается не везде. Возможно, это может быть связано с локальными погрешностями статистического учёта. Тем не менее, эта тенденция устойчива и прослеживается на составленных специалистами Всемирной Организации Здравоохранения картограммах частот суицидов ежегодно [4].

Приведённые расчёты и их графическое выражение позволяют утверждать, что суицидальность у людей есть больше биологическое, чем социальное явление. Поскольку, несмотря на значительные географические, климатические, экономические, культурные, пищевые, конфессиональные, социальные, этнические различия населения, проживающего в этих странах соотношение между числом суицидов между мужчинами и женщинами примерно одинаковое, а суицидов у мужчин всегда в разы больше, чем у женщин. В связи с представленными данными в качестве рабочей гипотезы таких различий можно выбрать генетические различия между мужчинами и женщинами. Некоторые авторы также предполагают, что нейробиология суицидального фенотипа может быть рассмотрена как функционирование единой полигенной метасистемы [10]. Соответственно, необходимо искать биологическую подоплеку суицидов, как мультифакториального фенотипа, завершением формирования которого является самоубийство, а внешние или коморбидные факторы влияют только на скорость окончательного формирования суицидального фенотипа и сроки наступления исхода.

Для подтверждения генетической природы половых (гендерных) различий самоубийств в обзор были отобраны работы, размещенные в свободном доступе в базе pubmed.ncbi.nlm.nih.gov, в которых гендерные различия связи каких-либо хромосомных локусов, однонуклеотидных полиморфизмов, измененной экспрессии генов или активности ферментов в связи с полиморфизмов их генов авторами недвусмысленно и однозначно были ассоциированы с суицидами в результате статистического сравнения частот выявленных генных аномалий у представителей мужского и женского полов. Были исключены работы, в которых суициды или суицидальные попытки совершались на фоне тяжёлых психических расстройств либо каких-либо аддикций, или в связи с актами насилия.

Целью работы является систематизация и интерпретация находящихся в свободном доступе, разрозненных, ранее установленных данных об ассоциации частот совершаемых суицидов с гендерными генетическими
When analyzing the cartogram, it seems that the gender coefficient as a whole decreases closer to the tropical zone, and vice versa, it increases getting close to the Arctic and Antarctic zones. But this not an overall rule. It may be caused by local errors of statistical accounting. Nevertheless, this trend is stable and can be traced on cartograms of suicide rates compiled by WHO specialists annually [4].

The above calculations and their graphical expression make it possible to assert that suicidality in people is more a biological than a social phenomenon. Hence, despite the significant geographic, climatic, economic, cultural, nutritional, confessional, social, ethnic differences of the population living in these countries, the ratio between the number of suicides between men and women is approximately the same, and the number of suicides among men are always many times higher than those among women. In connection with the presented data, genetic differences between men and women can be chosen as a working hypothesis of such differences. Some authors also suggest that the neurobiology of the suicidal phenotype can be considered as the functioning of a single polygenic metasystem [10]. Accordingly, it is necessary to look for the biological background of suicides as a multifactorial phenotype, the completion of the formation of which is suicide, and external or comorbid factors affect only the speed of the final formation of the suicidal phenotype and the timing of the onset of the outbreak.

To verify the genetic nature of sex (gender) differences in suicides, the review selected works that were freely available in the pubmed.ncbi.nlm.nih.gov database, in which gender differences in the relationship of any chromosomal loci, single nucleotide polymorphisms, altered gene expression or enzyme activity in connection with polymorphisms of their genes by the authors were explicitly and unambiguously associated with suicides as a result of a statistical comparison of the frequencies of identified gene abnormalities in males and females. The works where suicides or suicidal attempts were committed due to severe mental disorders or any addictions, or in connection with acts of violence were excluded.

The aim of the work is to systematize and interpret freely available, scattered, previously established data on the association of frequencies of committed suicides 
различиями, конечным итогом которой является формирование представления о гендерно различных паттернах генов, формирующих суицидальный фенотип у мужчин и женщин как минимум двумя разными генетически реализуемыми путями.

Х хромосома и суицид. Поставленная цель исследования сразу наводит на мысль, что такие различия могут связаны с половыми хромосомами. Действительно, в X хромосоме мужчин суицидентов обнаруживаются мутации, ассоциируемые с суицидами. Так у мужчин с завершённым суицидом в промоторной области SAT1 (локус Xp22.11) обнаружена аллель риска rs6526342. Присутствие этого аллеля в нейронах полей Бродмана $(B A) 4$, $B A 8 / 9$ и BA11 уменьшает экспрессию $S A T 1$ и, соответственно, синтез спермидин / спермин N1 - ацетилтрансферазы [11]. Кроме того, в промоторной области $S A T 1$ было обнаружено ещё три мутации - инсерция / делеция (rs6151267) и однонуклеотидный полиморфизм $r s 928931$ [12].

Продолжая это исследование, авторы генотипировали 37 микросателлитных маркеров, охватывающих всю $\mathrm{X}$ хромосому у 722 франко-канадских мужчин, среди которых не было родственников, из них 333 закончили жизнь суицидом, а 389 лиц без суицида (группа сравнения). Выявлено несколько индивидуальных маркеров, ассоциированных с суицидом. Обнаруженные маркеры тандемные повторы DXS8051 и DXS8102, а также $D X S 1001$ и $D X S 8106$ - локализовались в длинном и коротком плечах хромосомы X. После этого из материала, взятого в полях Бродмана 8/9, 11, 44 и 46, у суицидентов в X хромосомах было выявлено шесть экспрессированных генов: Rho GTPase-активирующего белка 6, адапторного белкового комплекса $1 \sigma 2$ субъединица, гликопротеина $M 6 B$, рибосомного белка $S 6$ киназы 90 кДа полипептид 3, спермидин / спермин N(1)-ацетилтрансферазы 1 и ТНО комплекс 2, - не экспрессировавшихся у субъектов группы сравнения [13].

У женщин, в отличие от мужчин, два однонуклеотидных полиморфизма ( $r s 4272555$ и $r s 2428707)$ гена серотонинового рецептора $H T R 2 C$ (локализация Xq23) acсоциированы с суицидальными попытками. Аллель rs4272555 был связан с уменьшением риска попытки самоубийства, тогда как аллель $r s 2428707$, напротив, оказался связан с увеличением риска попытки самоубийства [11]. Таким образом, у женщин на $\mathrm{X}$ хромосоме, повидимому, находятся гены как реализующие суицидентный фенотип, так и защищающие от суицидального поведения. Аналогичный результат связи полиморфизма G68C гена HTR2C с суицидами у женщин словенок получен при изучении 334 жертв самоубийств и 211 контрольных лиц женского пола [14]. with gender genetic differences, the final result of which is the formation of a concept of gender different patterns of genes that form the suicidal phenotype in men and women as at least two different genetically realized pathways.

$X$ chromosome and suicide. The stated aim of the study immediately suggests that such differences may be associated with sex chromosomes. Indeed, in the X chromosome of male suicide attempters, mutations associated with suicides are found. Thus, in men with completed suicide, the risk allele rs6526342 was found in the SAT1 promoter region (locus Xp22.11). The presence of this allele in the neurons of Brodmann's fields (BA) 4, BA8 / 9, and BA11 decreases the expression of SAT1 and, accordingly, the synthesis of spermidine/spermine N1acetyltransferase [11]. In addition, three more mutations were found in the SAT1 promoter region - insertion/deletion (rs6151267) and single nucleotide polymorphism rs928931 [12].

Continuing this study, the authors genotyped 37 microsatellite markers covering the entire X chromosome in 722 FrenchCanadian men, among whom there were no relatives, 333 of whom committed suicide, and 389 individuals didn't attempt suicide (comparison group). Several individual markers associated with suicide have been identified. The detected markers - tandem repeats of DXS8051 and DXS8102, as well as DXS1001 and DXS8106 - were localized in the long and short arms of the $\mathrm{X}$ chromosome. After that, from the material, in Brodmann fields 8/9, 11, 44 and 46 , in the suicides in the chromosomes taken six expressed genes were identified: Rho GTPaseactivating protein 6 , adapter protein complex $1 \sigma 2$ subunit, glycoprotein M6B, ribosomal protein S6 kinase $90 \mathrm{kDa}$ polypeptide 3, spermidine / spermine N (1) - acetyltransfer 1 and THO 2,- not expressed in subjects of the comparison group [13].

In women, unlike men, two single nucleotide polymorphisms (rs4272555 and rs2428707) of the serotonin receptor HTR2C gene (Xq23 localization) are associated with suicidal attempts. The rs4272555 allele was associated with a reduced risk of suicide attempt, while the rs2428707 allele, in contrast, was associated with a suicide risk trial [11]. Thus, in women on the $\mathrm{X}$ chromosome, apparently, there are genes both realizing the suicidal phenotype and protecting against 
Y хромосома и суищид. Данные о связи суицидального фенотипа и Y хромосомы парадоксальны, поскольку, как оказалось, суицид может быть связан с аберрантной потерей хромосомы Y, происходящей с возрастом - явление, известное более полувека [15]. Связь аберрантной потери хромосомы Y с суицидами была впервые выявлена на материале исследования посмертных образцов периферической крови и тканей мозга 286 мужчин жителей Японии (140 самоубийц без тяжелых физических заболеваний и 146 сопоставимых по возрасту контрольных испытуемых). У здоровых контрольных мужчин была обнаружена нормальная зависимая от возраста аберрантная потеря хромосомы Y в клетках крови. В клетках крови лиц, завершивших самоубийство, это явление встречалось значительно чаще, чем в контрольной группе (отношение шансов $=3,50,95 \%$ доверительный интервал $=$ 1,21-10,10). В клетках дорсолатеральной префронтальной коры головного мозга частота зависимой от возраста аберрантной потери хромосом Y не зависела от фенотипа [16]. Данное исследование, в частности, допустимо расценивать как механизм возрастного выравнивая гендерной дифференциации со стороны мужского пола. А возрастная аберрантная потеря хромосомы Y, считавшаяся изначально нейтральным кариотипом, связанным с нормальным старением, в настоящее время идентифицирована как наиболее распространённая приобретённая мутация в геноме мужчины, ассоциируемая с онкопатологией, болезнью Альцгеймера и сердечно-сосудистыми заболеваниями [17]. Следующий парадокс этой работы заключается в том, что явление аберрантной потери хромосомы Y, известное у людей почти 50 лет, по сути, является процессом диминуции ДНК. Но диминуция считается свойственной только некоторым эволюционно низшим эукариотам (например, копиподам), а у высших эукариот якобы отсутствует, поэтому все соматические клетки эукариот содержат одинаковый геном и это служит базовой основой для разработки методов клонирования. Однако это явление замечено и у людей, по крайней мере, для альфа-сателлитной ДНК - прицентромерный гетерохроматин [18]. Поскольку обнаружение связи аберрантной потери хромосомы Y с суицидами опубликовано в январе 2018 г., данное исследование ещё не подтверждено другими авторами.

При исследовании митохондриальных гаплотипов в Европейской популяции у мужчин была выявлена связь гаплотипов N и R1a Y-ДНК как убийствами, так и с суицидами, в то время как гаплотип I1 с убийствами и суицидами коррелировал отрицательно. У женщин гаплогруппы L, J и X мтДНК с суицидом коррелировали отрицательно. Авторы исследования подчеркивают, что их данные не означают, что митохондриальные гаплотипы suicidal behavior. A similar result of the relationship between the $\mathrm{G} 68 \mathrm{C}$ polymorphism of the HTR2C gene and suicides in female Slovenian women was obtained in a study of 334 suicides and 211 control females [14].

$Y$ chromosome and suicide. The data on the relationship between the suicidal phenotype and the Y chromosome are paradoxical, since, as it turned out, suicide may be associated with an aberrant loss of the Y chromosome that occurs with age - a phenomenon that has been known for more than half a century [15]. The association of aberrant loss of chromosome $\mathrm{Y}$ with suicides was first revealed on the material of a postmortem samples study of peripheral blood and brain tissue of 286 male residents of Japan (140 suicides without serious physical diseases and 146 age-matched control subjects). In healthy control males, a normal age-dependent aberrant loss of the Y chromosome in blood cells was found. In the blood cells of individuals who completed suicide, this phenomenon was encountered significantly more often than in the control group (odds ratio $=3.50,95 \%$ confidence interval $=1.21-10.10)$. In cells of the dorsolateral prefrontal cortex, the frequency of age-dependent aberrant loss of Y chromosomes did not depend on the phenotype [16]. This study, in particular, can be regarded as a mechanism of age leveling of gender differentiation on the part of the male sex. And age-related aberrant loss of the $\mathrm{Y}$ chromosome, which was initially considered a neutral karyotype associated with normal aging, is currently identified as the most common acquired mutation in the male genome associated with cancer, Alzheimer's disease and cardiovascular diseases [17]. The next paradox of this work is that the phenomenon of aberrant loss of the $\mathrm{Y}$ chromosome, which has been known in humans for almost 50 years, is, in fact, a process of DNA diminution. But diminution is considered characteristic only of some evolutionarily lower eukaryotes (for example, copipods), while in higher eukaryotes it is allegedly absent, therefore all somatic cells of eukaryotes contain the same genome, which serves as the basis for the development of cloning methods. However, this phenomenon has also been observed in humans, at least for alpha-satellite DNA - pricentromeric heterochromatin [18]. Since the discovery of the association of aberrant loss of the $\mathrm{Y}$ chro- 
являются маркерами суицидального фенотипа. Тем не менее, выявленная связь может говорить о том, что суицидальность имеет сильную биологическую составляющую [19].

Генные полиморфизмы, возможно участвующие в реализачии гендерного парадокса, но не связанные $c X$ хромосомой. В тех случаях, когда прямое наблюдение на людях невозможно, ответ может быть получен в эксперименте на животных. У потомков обоего пола мышей линии $C 57 B L / 6 J$, скрещиваемых на протяжении восьми поколений с мышами линии 129Jaе для получения делеции Dnmt3a $\mathrm{a}^{2 \operatorname{lox} / 2 \operatorname{lox}}$ (делеция гена (цитозин-5)метилтрансферазы $3 \mathrm{~A}$ - фермент, катализирующий перенос метильных групп к сайтам метилирования), в хвостатом ядре в ответ на стресс, формирующий модель депрессивного состояния, образовывались различающиеся паттерны транскрипционной регуляции. Половая специфика паттернов была обусловлена различиями активности ДНК-метилтрансферазы у самцов и самок в этом подкорковом ядре головного мозга. То есть, половые различия паттернов были связаны с эпигенетическим механизмом регуляции транскрипции путем метилирования неких участков ДНК, связанных с reward системой. Блокирование этого эпигенетического механизма сопровождалось поведенческой устойчивостью самок к стрессу [20].

Гендерная специфика паттернов экспрессии генов, ассоциируемых с суицидами найдена и у людей. Так в материале аутопсий дорсолатеральной префронтальной коры 75 латиноамериканцев (38 суицидентов мужчин и 10 женщин, группа сравнения 20 мужчин и 7 женщин выявлено 1729 экспрессированных генов у женщин и 997 у мужчин. У женщин, гены, ассоциированные с суицидом, были связаны с пролиферацией клеток и иммунным ответом, а у мужчин с суицидом оказались ассоциированы гены, связанные с ДНК и рибонуклеиновым белковым комплексом. Не связанные с полом гены, ассоциируемые с суицидом, были обнаружены в митохондриальном геноме [21]. Выявленную специфику экспрессии в префронтальной коре мужчин генов, связанных с ДНК и рибонуклеиновым белковым комплексом допустимо объяснить тем, что у мужчин-суицидентов в когорте из 120 пациентов фактором риска высокой летальности при суицидальных попытках был полиморфизм гена нейротрофического фактора роста BDNF Val66Met rs6265 (локализация $11 \mathrm{p} 14.1$ ) [22]. Метаанализ 12 работ, посвящённых полиморфизмам гена $B D N F$, позволил сделать вывод, что комбинированные генотипы BDNF Met66Met и BDNF Met6Val могут быть фактором риска насильственного самоубийства у женщин и самоубийства у жертв, подвергшихся детской травме [23]. mosome with suicide was published in January 2018, this study has not yet been confirmed by other authors.

In the study of mitochondrial haplotypes in the European population in men, a relationship was found between the $\mathrm{N}$ and R1a Y-DNA haplotypes with both murders and suicides, while the I1 haplotype correlated negatively with murders and suicides. In women, mtDNA haplogroups $\mathrm{L}, \mathrm{J}$, and $\mathrm{X}$ correlated negatively with suicide. The authors of the study emphasize that their data does not mean that mitochondrial haplotypes are markers of the suicidal phenotype. Nevertheless, the revealed connection may indicate that suicidality has a strong biological component [19].

Gene polymorphisms, possibly taking part in the gender paradox realization, but not associated with the $X$ chromosome. In cases where direct observation in humans is not possible, the answer can be obtained in animal experiments. In the offspring of C57BL/6J mice, crossed for eight generations with 129Jae mice to obtain a $D n m t 3 a^{2 l o x / 2 l o x}$ deletion (deletion of the (cytosine-5) methyltransferase 3A gene, an enzyme that catalyzes the transfer of methyl groups to methylation sites) in the caudate nucleus, in response to stress, which forms the model of the depressive state, different patterns of transcriptional regulation were formed. The gender specificity of the patterns was caused by the differences in the activity of DNA methyltransferase in males and females in this subcortical nucleus of the brain. That is, sex differences in patterns were associated with the epigenetic mechanism of regulation of transcription by methylation of certain DNA regions associated with the reward system. Blocking this epigenetic mechanism was accompanied by female behavioral resistance to stress [20].

The gender specificity of the patterns of gene expression associated with suicide has also been found in humans. Thus, in the autopsy material of the dorsolateral prefrontal cortex of 75 Hispanics (38 suicides in men and 10 women, a comparison group of 20 men and 7 women, 1729 expressed genes were found in women and 997 in men. In women, genes associated with suicide were related to proliferation cells and immune response, and in men genes associated with suicide turned out to be related to DNA and ribonucleic protein complex. Sex-free genes associated with suicide were found in the 
В результате полногеномного поиска ассоциаций в локусе 2 p25 в образцах головного мозга мужчин самоубийц, но не женщин обнаружены гены SH3YL1 (ген эволюционно консервативного белка корегулятора андрогенного рецептора) и АСР1 (ген кислой фосфатазы), ассоциированных с суицидами [24]. В многофакторном исследовании взаимодействия генома с окружающей средой в популяции из 123633 человек идентифицированы расположенные в локусе $2 q 31.3$ гены сплайсосомаассоциированного белка гомолога $C W C 22$ (полиморфизм $r s 2367967)$ и $U B E 2 E 3$, связанные с суицидами у мужчин [25].

Гендерные различия у суицидентов наблюдаются и в экспрессии генов медиаторных систем. Например, у женщины суицидентов экспрессия гена везикулярного транспортера глутамата VGLUT (локализация 11q23.3) была значительно выше по сравнению с женщинами не суицидентами. Тогда как экспрессия глиального высокоаффинного транспортера глутамата EAAT (локализация 5 13.2) была ниже у мужчин, совершивших насильственные самоубийства [26]. Среди 180 самоубийц (121 женщина и 59 мужчин) и 212 контрольных доноров крови (93 женщины и 119 мужчин) в группе женщин самоубийц выявлена высокая экспрессия транспортера серотонина, по-видимому, вызванная удлинением промоторной области. Тогда как у мужчин самоубийц и женщин с незавершённым суицидом, вследствие низкого уровня аутоагрессии, экспрессия транспортера серотонина была низкой [27]. Следует заметить, что авторы были осторожны в своих оценках, поскольку посчитали, что набранная ими группа количественно недостаточна для формирования окончательных выводов.

Исследование этими же авторами частот встречаемости полиморфизма гена транспортера серотонина с более длинной промоторной областью, позволило выявить что этот полиморфизм у женщин, совершивших летальный суицид, встречался в $41 \%$ случаев, что значительно чаще, чем в общей популяции - 15,5\% [28]. Тем не менее, в трёх метаанализах, где не ставилась цель выявления гендерных различий генетических причин суицидов, связь полиморфизма гена транспортера серотонина с более длинной промоторной областью с насильственными самоубийствами, но не с ненасильственными суицидами, оказалась высокой [29]. Как видим, различия подходов к формированию групп статистического исследования могут давать разные результаты, особенно, если группы малые, а отбор был тенденциозен. Исследование ассоциации гена белка переносчика серотонина $S L C 6 A 4$ (локализация $17 q 11.2$ ) в российской популяции суицидентов также выявило связь этого гена с суицидом только у женщин, но не у мужчин [30]. mitochondrial genome [21]. Revealed specificity of expression in the prefrontal cortex of men genes associated with DNA and ribonuclein protein complex can be explained by the fact that in male cohort of 120 suicide attempters the risk factor for high mortality in suicidal attempts was polymorphism of the gene for the neurotrophic growth factor BDNF Val66Met rs6265 (localization 11p14.1) [ 22]. Meta-analysis of 12 works devoted to polymorphisms of the BDNF gene made it possible to conclude that the combined genes The $B D N F$ Met66Met and BDNF Met6Val types may be a risk factor for violent suicide in women and suicide in victims of childhood trauma [23].

As a result of a complete genome search for associations at the $2 \mathrm{p} 25$ locus in the brain samples of suicidal men but not women, the genes SH3YL1 (gene for the evolutionarily conserved protein of the androgen receptor co-regulator) and $A C P 1$ (gene for acid phosphatase) were found to be associated with suicides [24]. In a multifactorial study of the interaction of the genome with the environment in a population of 123,633 people, the genes of the spliceosome-associated protein of the homologue $C W C 22$ (polymorphism rs2367967) and $U B E 2 E 3$, associated with suicides in men, located at the $2 q 31.3$ locus were identified [25].

Gender differences in suicides are also observed in the expression of genes of mediator systems. For example, in a suicidal woman, the expression of the vesicular glutamate transporter gene VGLUT (localization 11q23.3) was significantly higher than in women who were not suicidal. Whereas the expression of glial high-affinity glutamate transporter EAAT (localization 5p13.2) was lower in men who committed violent suicide [26]. Among 180 suicides (121 women and 59 men) and 212 control blood donors (93 women and 119 men), high expression of the serotonin transporter was revealed in the group of female suicide attempters, apparently caused by the elongation of the promoter region. However, expression of the serotonin transporter was low in men who commit suicide and women with incomplete suicide due to a low level of autoaggression [27]. It should be noted that the authors were cautious in their assessments, since they considered that the group they had recruited was quantitatively insuf- 
Полиморфизмы гена 5-HTR6 267C/T, локализованного в сегменте $1 p 36.13$, были исследованы в образцах крови в португальской популяции у 179 мужчин суицидентов и 189 добровольцев, не склонных к суициду. При сравнении распределения генотипов между мужчинамижертвами суицида и мужчинами не суицидентами выявлена гендерно-специфическая связь, предполагающая, что этот однонуклеотидный полиморфизм может иметь роль в этиологии суицида у мужчин-испытуемых в португальской популяции [31].

Предполагается, что одной из генетических причин суицидов у мужчин может быть полиморфизм катехолоксиметилтрансферазы (КОМТ). При генотипе Val/Val активность КОМТ в три-четыре раза выше, чем при генотипе Met/Met, а при генотипе Val/Met ферментативная активность имеет промежуточное значение [32]. Действительно, полиморфизм гена КОМТ Val158Met (rs4680) оказался статистически значимо связан с насильственными суицидами у мужчин этнических японцев в выборке из 163 суицидентов с завершённым суицидом (112 мужчин, 51 женщина), тогда как полиморфизм Val158 Val, возможно, ассоциирован с уменьшением числа самоубийств [33]. Результаты этого исследования были подтверждены при исследовании связи суицидов с полиморфизмом Val158Met (rs4680) у этнических корейцев мужчин (70 суицидентов мужчин и 127 женщин, против группы сравнения мужчины : женщины $=85: 85)$. Как и в предыдущем исследовании, связи полиморфизма $r s 4680$ с суицидами у женщин не обнаружено [34]. Кроме полиморфизмов КОМТ, полоспецифично с суицидами оказался связан и полиморфизм EcoRV гена $\mathrm{MAO}_{\mathrm{A}}$, который был найден в посмертных образцах мозга 44 депрессивных мужчин самоубийц, но не у 92 контрольных испытуемых мужчин, и не у женщин, и не в общей выборке [35]. Аналогичная связь полиморфизма Val158Met с не насильственными и насильственными суицидами у мужчин, но не у женщин и не у добровольцев найдена среди 365 жертв суицида у мужчин европейцев [36], а также 70 этнических корейцев мужского пола [37].

Реализация влияния внешних факторов, считающиеся приоритетными причинами суицидов в социологических и психических теориях формирования суицидентного фенотипа, может быть осуществлена через взаимодействие с первичным генным дефектом. Например, в посмертном токсикологическом скрининге, охватившем 349 завершённых суицидентов и 284 контрольных случаев, было показано что женщины с гаплотипом гена гликопротеина-Р АВCB1 1236T-2677T-3435T, употребляющие циталопрам, чаще совершали ненасильственные самоубийства (отравление циталопрамом), чем в группе ficient to form final conclusions.

A study by the same authors of the frequency of occurrence of serotonin transporter gene polymorphism with a longer promoter region revealed that this polymorphism in women who committed lethal suicide occurred in $41 \%$ of cases, which is much more frequent than in the general population $-15,5 \%$ [28]. However, in three meta-analyzes that did not aim to identify gender differences in the genetic causes of suicide, the association of serotonin transporter gene polymorphism with a longer promoter region was high for violent suicide, but not for non-violent suicide [29]. As you can see, differences in approaches to the formation of groups of statistical research can give different results, especially if the groups are small, and the selection is tendentious. The study of the association of the gene for the serotonin transporter protein SLC6A4 (localization 17q11.2) in Russian population of suicide attempters also revealed an association of this gene with suicide only in women, but not in men [30].

Polymorphisms of the 5-HTR6 267C/T gene located in the $1 p 36.13$ segment were studied in blood samples from a Portuguese population of 179 suicidal men and 189 nonsuicidal volunteers. When comparing the distribution of genotypes between male suicide victims and male non-suicides, a gender-specific relationship was revealed, suggesting that this single nucleotide polymorphism may have a role in the etiology of suicide in male subjects in the Portuguese population [31].

It is assumed that one of the genetic causes of suicide in men may be influenced by polymorphism of catecholoxymethyltransferase (COMT). In the Val/Val genotype, the COMT activity is three to four times higher than in the Met/Met genotype, while in the Val/Met genotype the enzymatic activity has an intermediate value [32]. Indeed, the polymorphism of the COMT Val158Met gene (rs4680) was statistically significantly associated with violent suicides in ethnic Japanese men in a sample of 163 suicide attempters with completed suicide (112 men, 51 women), while the Val158 Val polymorphism is possibly associated with a decrease in the number of suicide [33]. The results of this study were verified by a study of the association of suicides with the Val158Met polymorphism ( $r s 4680)$ in ethnic Korean men (70 male suicide attempters and 
сравнения [38]. По-видимому, полиморфизмы гена ABCB1 вовсе не безобидны. Из результатов 998 судебных вскрытий лиц от 18 лет и старше швейцарской популяции без учета пола следует, что частота аллеля Т в позициях 1236, 2677 и 3435 гена АВСB1 у суицидентов была значительно выше, чем у умерших по естественным причинам и в результате несчастных случаев [39]. Сопоставляя эти факты, можно сделать вывод, что ген, полиморфизм которого и без того ассоциирован с суицидами, увеличивает риск совершения суицида пациентками, принимающими циталопрам, который в данной ситуации играет роль триггера, реализующего суицид. Поскольку гликопротеин-Р является неспецифическим переносчиком ксенобиотиков, можно думать, что полиморфизмы его гена меняют фармакокинетику циталопрама, что сопровождается либо накоплением препарата в организме, либо ускоренным выведением. Очевидно, что и то и другое меняет клинический эффект в неблагоприятную сторону, вынуждая совершить суицид. Полиморфизмы гена ABCB1 1236TT, 2677TT, 3435TT также оказались связанными с трёхкратным увеличением риска у женщин, впервые пытавшихся совершить насильственное самоубийство [40].

Установление связи полиморфизма какого-либо гена с суицидальным фенотипом является сложной задачей, если не учитывать дополнительные факторы и использовать малые выборки. Так, например, ни в одном исследовании не было выявлено связи между геном SIRT1 и завершённым самоубийством (продукты генов семейства SIRT - эволюционно консервативные НАД-зависимые диацетилазы или АДФ - рибозилтрансферазы). Но при исследовании в японской популяции больных с маниакально-депрессивным психозом 778 случаев завершённых суицидов при сравнении с 760 несуицидентами, обнаружена значимая связь между однонуклеотидного полиморфизма $r s 12415800$, расположенным вблизи с геном $S I R T 1$ с завершёнными суицидами среди женщин в возрасте старше 50 лет. В результате дополнительного исследования того же материла было установлено, что экспрессия гена $S I R T 1$ в префронтальной коре не отличалась между тканями мозга самоубийц и не самоубийц, но была значительно снижена экспрессия гена DNAJC12 (локализация 10q21.3) - гена белков-шаперонов HSP40 белков HSP70, потенциально вовлеченного в экспрессию полиморфного варианта $r s 12415800$ гена SIRT1 [41]. Tо есть, данное исследование позволило установить связь однонуклеотидного полиморфизма с суицидами только в результате учёта взаимодействия нескольких элементов дизайна исследования - количественно значительная группа обследованных и учёт таких факторов, как: пол, возраст и вовлечённость в процесс второго гена.
127 female attempters, versus the comparison group male: female $=85: 85$ ). As in the previous study, no association of rs 4680 polymorphism with suicide was found in women [34]. In addition to the COMT polymorphisms, the EcoRV polymorphism of the $M A O A$ gene, which was found in postmortem brain samples of 44 depressed suicidal men, but not in 92 control male subjects, and not in women, and not in the general sample [35]. A similar association of the Val158Met polymorphism with non-violent and violent suicides in men, but not in women and not in volunteers, was found among 365 European male suicide victims [36], as well as 70 male ethnic Koreans [37].

The implementation of the influence of external factors, which are considered priority causes of suicide in sociological and mental theories of the formation of a suicidal phenotype, can be carried out through interaction with a primary gene defect. For example, in the postmortem toxicological screening, which covered 349 completed suicide attempters and 284 control cases, it was shown that women with the haplotype of the glycoprotein-P $A B C B 1$ gene $1236 T$ 2677T-3435T who consumed citalopram were more likely to commit non-violent suicide (by citalopram intake) than in the comparison group [38]. Apparently, the $\mathrm{ABCB} 1$ gene polymorphisms are not at all harmless. From the results of 998 forensic autopsies of persons aged 18 and older in the Swiss population regardless of gender, it follows that the frequency of the $\mathrm{T}$ allele in positions 1236, 2677 and 3435 of the $\mathrm{ABCB} 1$ gene in suicide attempters was significantly higher than in those who died from natural causes and as a result of accidents [39]. Comparing these facts, we can conclude that the gene whose polymorphism is already associated with suicide, increases the risk of suicide in patients taking citalopram, which in this situation plays the role of a suicide trigger. Since glyco-protein-P is a nonspecific carrier of xenobiotics, one can think that polymorphisms of its gene change the pharmacokinetics of citalopram, which is accompanied either by the accumulation of the drug in the body or by accelerated excretion. Obviously, both of them change the clinical effect in an unfavorable direction, forcing to commit suicide. Polymorphisms of the ABCB1 gene 1236TT, 2677TT, 3435TT were also associated with a threefold increase in risk in women who first 
Для удобства восприятия изложенного материла гендерные паттерны генов, ассоциированных с суицидами у мужчин и женщин сведены в табл. 2.

Таблица / Table 2

Гендерные паттерны генов, ассоциированные с суицидами Gender Genetic Patterns Associated with Suicide

Паттерн генов, ассоциированный с суицидами у Gender Genetic Patterns Associated with Suicide of

\begin{tabular}{|c|c|}
\hline Мужчин / Males & Женщин / Females \\
\hline \multicolumn{2}{|c|}{$\begin{array}{l}\text { Локусы и гены, связанные с хромосомой X } \\
\text { Loci and genes associated with X chromosome }\end{array}$} \\
\hline \multicolumn{2}{|l|}{$\overline{\mathrm{Xp} 11.3, \mathrm{MAO}_{\mathrm{A}}}$} \\
\hline \multicolumn{2}{|l|}{$\begin{array}{l}\text { Xp21.1-p11.4, тандемный повтор } \\
\text { DXS8102 } \\
\text { tandem repeat DXS8102 }\end{array}$} \\
\hline \multicolumn{2}{|l|}{ Xp22.11, SAT1 } \\
\hline \multicolumn{2}{|l|}{ Xp22.12, RPS6KA3 } \\
\hline \multicolumn{2}{|l|}{$\begin{array}{l}\text { Xp22.2, тандемный повтор DXS8051 } \\
\text { tandem repeat DXS8051 }\end{array}$} \\
\hline \multicolumn{2}{|l|}{ Xp22.2, ARHGAP6 } \\
\hline \multicolumn{2}{|l|}{ Xp22.2, GPM6B } \\
\hline & Xq23, HTR2C \\
\hline \multicolumn{2}{|l|}{$\begin{array}{l}\text { Xq24, тандемный повтор DXS1001 } \\
\text { tandem repeat DXS1001 }\end{array}$} \\
\hline \multicolumn{2}{|l|}{$\mathrm{Xq} 25$, THOC2 } \\
\hline $\begin{array}{l}\text { Xq26, тандемный повтор DXS8106 } \\
\text { tandem repeat DXS8106 }\end{array}$ & \\
\hline
\end{tabular}

Локусы и гены, связанные с хромосомой Y

Loci and genes associated with Y chromosome

\begin{tabular}{|c|c|}
\hline $\begin{array}{l}\text { Возрастная аберрантная потеря хромосомь } \\
\text { Y клетками крови / Age aberrant loss of Y } \\
\text { chromosome by blood cells }\end{array}$ & - \\
\hline Yp11.2, ASMTL и ASMT & - \\
\hline
\end{tabular}

Локусы и гены, связанные с соматическими хромосомами Loci and genes associated with autosomes

\begin{tabular}{l|r}
\hline $1 \mathrm{p} 36.13,5-\mathrm{HTR} 6$ & \\
\hline $2 \mathrm{p} 25.3, \mathrm{SH} 3 \mathrm{YL} 1$ & \\
\hline $2 \mathrm{p} 25.3, \mathrm{ACP} 1$ & \\
\hline $2 \mathrm{q} 31.3, \mathrm{CWC} 22$ & \\
\hline $2 \mathrm{q} 31.3, \mathrm{UBE} 2 \mathrm{E} 3$ & $7 \mathrm{q} 21.12$, ABCB1 \\
\hline $5 p 13.2, \mathrm{EAAT}$ & $10 \mathrm{q} 21.3, \mathrm{SIRT} 1$ \\
\hline $7 \mathrm{q} 22.1, \mathrm{AP} 1 \mathrm{~S} 1$ & $10 \mathrm{q} 21.3$, DNAJC12 \\
\hline & $11 \mathrm{q} 23.3$, VGLUT \\
\hline $11 \mathrm{p} 14.1, \mathrm{BDNF}$ & $17 \mathrm{q} 11.2$, SLC6A4 \\
\hline & \\
\hline $19 \mathrm{q} 13.32, \mathrm{AP} 2 \mathrm{~S} 1$ & \\
\hline $22 \mathrm{q} 11.21, \mathrm{COMT}$ & \\
\hline
\end{tabular}

attempted violent suicide [40].

Establishing a relationship between the polymorphism of a gene and a suicidal phenotype is a difficult task, if additional factors are not taken into account and small samples are used. For example, no study has identified an association between the SIRT1 gene and completed suicide (products of the SIRT family genes are evolutionarily conserved NAD-dependent diacetylases or ADPribosyltransferases). But in a study of 778 cases of completed suicide attempters in the Japanese population of patients with manicdepressive psychosis, compared with 760 non-suicide attempters, a significant association was found between the single nucleotide polymorphism rs 12415800 , located close to the SIRT1 gene with completed suicides among women over the age of 50 . As a result of an additional study of the same material, it was found that the expression of the SIRTI gene in the prefrontal cortex did not differ between the brain tissues of suicide attempters and non-suicide attempters, but the expression of the DNAJC12 gene (localization 10q21.3), the gene of HSP 40 protein chaperones proteins HSP70 was significantly reduced potentially involved in the expression of the polymorphic variant $r s 12415800$ of the SIRT1 gene [41]. That is, this study made it possible to establish the relationship of singlenucleotide polymorphism with suicides only as a result of taking into account the interaction of several elements of the study design - a quantitatively significant group of subjects and taking into account such factors as gender, age and involvement of the second gene in the process. For the convenience of perceiving the stated material, the gender patterns of genes associated with suicides in men and women are summarized in Table. 2 . It should be clarified that, speaking about the pattern of genes, the authors do not mean that this is a gene network, it may be genes that are included in different gene networks, since the gene patterns associated with suicides, characteristic of males or females, do not coincide in terms of quality composition.

As you can see, the largest number of genes associated with suicide in males is localized on the X chromosome. Since men do not have paired alleles of $\mathrm{X}$ chromosome genes without corresponding polymorphisms (hemizygous state), polymorphic genes will realize a suicidal phenotype, in contrast to women heterozygous for these polymor- 
Следует уточнить, что, говоря о паттерне генов, авторы не имеют в виду, что это генная сеть, это могут быть гены, входящие в разные генные сети, поскольку ассоциируемые с суицидами паттерны генов, характерные для мужского или женского пола, не совпадают по качественному составу.

Как видим, наибольшее число генов, ассоциированное с суицидом у мужчин, локализовано в хромосоме $X$. Поскольку у мужчин отсутствуют парные аллели генов $X$ хромосомы без соответствующих полиморфизмов (гемизиготное состояние), полиморфные гены будут реализовывать суицидальный фенотип, в отличие от гетерозиготных по этим полиморфизмам женщин, у которых активность измененных генов нивелируется их «правильными» копиями. Тогда как у женщин, гомозиготных по этим полиморфизмам, их функциональность, приводящая к печальному жизненному исходу, может реализоваться в более ярком фенотипическом проявлении, чем у мужчин. Как мы уже упоминали во введении, полиморфные локусы у женщин могут быть инактивированы нормальными копиями генов, соответственно, повреждающий эффект полиморфизма не будет реализован. Защита от дефектных копий генов хромосомы $X$ может реализоваться в процессе импринтированной инактивации хромосомы $X$ у женщин, когда из генома женщины в виде тельца Барра исключается отцовская, но не материнская хромосома $X$ [42].

В соответствии с результатами секвенирования по состоянию на 2017 г. хромосома $Y$ человека содержит 98 кодирующих белок генов [43]. Поэтому возрастная аберрантная потеря хромосомы $Y$ клетками крови, которая сама по себе может быть лишь маркером более широкого явления, то есть - потери хромосомы $Y$ в том числе нейронами, может сопровождаться значительными метаболическим изменениями, усугубляющими врожденный дисметаболизм. Среди этих 98 белков есть, например, кодируемый геном ASMTL $N$-ацетилсеротонин $O$ метилтрансферазоподобный белок (Yр11.2), выполняющий функцию КОМТ [44]. Исходя из предыдущего изложения, полиморфизм КОМТ, связанный с уменьшением активности этого фермента, ассоциирован с суицидами у мужчин $[32,33]$. В том же локусе Yp11.2 локализован ген ASMT (метилтрансфераза ацетилсеротонина) продукт которого также является КОМТ и также участвует в синтезе мелатонина [43]. Очевидно, что элиминация генов $A S M T L$ и $A S M T$ из генома по крайней мере части нейронов должна сопровождаться ещё большим угнетением активности КОМТ, связанной с полиморфизмом $r s 4680$. Исходя из функции этих генов, также очевидно, что дефицит их экспрессии должен сопровождаться уменьшением плазменных концентраций мелато- phisms, in whom the activity of the altered genes is leveled by their "correct" copies. Still in women who are homozygous for these polymorphisms, their functionality, leading to a sad life outcome, can be realized in a more vivid phenotypic manifestation than in men. As we already mentioned in the introduction, polymorphic loci in women can be inactivated by normal copies of genes; accordingly, the damaging effect of polymorphism will not be realized. Protection against defective copies of $\mathrm{X}$ chromosome genes can be realized in the process of imprinted inactivation of the $\mathrm{X}$ chromosome in women, when the paternal but not the maternal $\mathrm{X}$ chromosome is excluded from the woman's genome in the form of a Barr body [42].

According to the sequencing results as of 2017, the human Y chromosome contains 98 protein-coding genes [43]. Therefore, age-related aberrant loss of the $\mathrm{Y}$ chromosome by blood cells, which in itself can only be a marker of a broader phenomenon, that is, the loss of the $\mathrm{Y}$ chromosome, including neurons, can be accompanied by significant metabolic changes that aggravate congenital dysmetabolism. Among these 98 proteins, there is, for example, the $\mathrm{N}$-acetylserotonin O-methyltransferase-like protein (Yp 11.2) encoded by the ASMTL gene, which performs the function of COMT [44]. Based on the previous discussion, the COMT polymorphism associated with a decrease in the activity of this enzyme is associated with suicide in men $[32,33]$. The $A S M T$ gene (acetyl serotonin methyltransferase) gene is localized in the same Yp11.2 locus also has COMT as its product and is also involved in melatonin synthesis [43]. It is obvious that the elimination of the ASMTL and ASMT genes from the genome of at least some neurons should be accompanied by an even greater inhibition of the COMT activity associated with the rs 4680 polymorphism. Based on the function of these genes, it is also obvious that a deficiency in their expression should be accompanied by a decrease in plasma melatonin concentrations. There are sufficient grounds to believe that the age-related decrease in plasma melatonin concentrations leads not only to sleep disturbances, but also to depressive disorders [45]. The functions of the remaining 96 genes of the $\mathrm{Y}$ chromosome, at first glance, are in no way associated with the pattern of genes we have collected that are associated with suicide in men. 
нина. Есть достаточные основания полагать, что возрастное уменьшение плазменных концентраций мелатонина приводит не только к нарушениям сна, но и к депрессивным расстройствам [45]. Функции остальных 96 генов хромосомы $Y$, на первый взгляд, никак не ассоциируются с собранным нами паттерном генов, ассоциируемых с суицидами у мужчин.

Вторым лидером по количеству генов, ассоциированных с суицидом у мужчин, является хромосома 2 . По одному ассоциированному гену локализовано на хромосомах $1,5,7,11,19,22$. В целом эти гены можно охарактеризовать как вовлечённые в гормональную (андрогенную) и тормозную медиаторную регуляцию (ГАМК и серотонинергическую), либо транспорт белков, либо убиквитин-зависимое разрушение белков, пролиферацию нейронов. В целом, можно предполагать, что ассоциация этих генов с суицидами у мужчин может быть обусловлена нарушением неких регуляторных путей, реализующих высшие психические функции.

Гены, ассоциированные с суицидами у женщин, это регуляторы серотониновой системы (HTR2C, SLC6A4), либо выведения ксенобиотиков из клеток $(A B C B 1)$, либо активности гистоновых белков (сиртуины, $V G L U T)$, либо процессов фолдинга белков (DNAJC12). В целом этот паттерн генов можно охарактеризовать как регуляторы внутриклеточных процессов. То есть, если у мужчин паттерн генов, ассоциированных с суицидом, в большей степени связан межклеточной сигнализацией, то у женщин - с внутриклеточным сигналингом.

Таким образом, можно выделить три паттерна генов, ассоциированных с суицидами, а именно паттерн генов, ассоциированных с суицидами:

1) у мужчин,

2) женщин,

3) не ассоциируемых с гендерной (половой) принадлежностью.

Проведённый анализ данных литературы о связи суицидов с генетическими различиями полов позволяет сделать заключение, что различия частот суицидов среди мужчин и женщин сохраняются вне зависимости от географического положения, страны проживания, социального, политического, экономического состояния государств. В тех географических районах, где частота суицидов выше, чем в среднем, при сохранности гендерного парадокса она одинаково выше для обоих полов. Если внешние условия (чаще экономические изменения) экстремально увеличивают частоту суицидов - гендерный разрыв всё равно продолжает сохраняться и не становится ничуть не меньше. Тогда как увеличение гендерного коэффициента за счёт роста числа суицидов у мужчин как раз, может быть, следствием давления внешних
The second leader in terms of the number of genes associated with suicide in men is chromosome 2. One associated gene is localized on chromosomes $1,5,7,11,19$, 22. In general, these genes can be characterized as involved in hormonal (androgenic) and inhibitory mediator regulation (GABA and serotonergic), or protein transport, or ubiquitin-dependent protein destruction, neuronal proliferation. In general, it can be assumed that the association of these genes with suicides in men may be caused by a violation of certain regulatory pathways that implement higher mental functions.

The genes associated with suicides in women are regulators of the serotonin system (HTR2C, SLC6A4), or the removal of xenobiotics from cells $(A B C B 1)$, or the activity of histone proteins (sirtuins, VGLUT), or protein folding processes (DNAJC12). In general, this pattern of genes can be characterized as regulators of intracellular processes.

That is, if in men the pattern of genes associated with suicide is more associated with intercellular signaling, then in women it is associated with intracellular signaling.

Thus, three patterns of genes associated with suicide can be distinguished, namely, the pattern of genes associated with suicide:

1) in men,

2) in women,

3) not associated with gender (sex) identity.

The analysis of the literature data on the connection of suicides with genetic gender differences allows us to conclude that the differences in the frequencies of suicides among men and women persist regardless of geographic location, country of residence, social, political, and economic state of states. In those geographic areas where the suicide rate is above average, while the gender paradox persists, it is equally higher for both sexes. If external conditions (more often economic changes) extremely increase the frequency of suicides, the gender gap still continues to persist and does not get any less. Whereas the increase in the gender coefficient due to the increase in the number of suicides in men is just, perhaps, a consequence of the pressure of external factors that implement multifactorial pathology.

Since the behavioral suicidal phenotype differs in representatives of different sexes [2], it can be assumed that it is a secondary derivative of the genetic mechanisms 
факторов, реализующих мультифакториальную патологию.

Поскольку поведенческий суицидальный фенотип у представителей разного пола отличается [2], можно предположить, что он является вторичным производным от генетических механизмов формирования морфологических половых отличий в том смысле, что первичная половая дифференцировка в конечном итоге приводит к созданию различающихся по генному составу генных сетей, формирующих соответствующие поведенческие и психические стереотипы, в том числе - патологические. То есть, первичные изменения экспрессии эмбриональных генов, обеспечивающие образование первичных половых признаков, в последующем вызывают экспрессию и образование различных генных сетей у полов. Если в эти сети попадают гены с какими-либо полиморфизмами, их экспрессия меняет конечный результат работы всей сети с реализацией эволюционно проигрышного или биологически индифферентного фенотипа. Соответственно, в филогенезе могли выработаться гены, препятствующие реализации эволюционно проигрышного индивидуального фенотипа, если такой фенотип угрожает существованию вида в целом. Материнские гены супрессоры генома, передаваемого потомству самцом, реализующие супрессивный эффект в том случае, если в геноме отца есть гены, экспрессия которых угрожает гибели потомства, к настоящему времени найдены по крайней мере у чешуекрылых насекомых $[46,49]$.

Известно, что более $50 \%$ завершённых суицидов совершены людьми без известных психических заболеваний. Поэтому было высказано предложение, что суицидальность следует рассматривать как особый психиатрический диагно3, с его симптомами и отщепляющими патологическими процессами [48]. Это хорошо согласуется с нашей идеей о том, что суицидальный фенотип необходимо рассматривать как мультифакториальное состояние, завершающееся суицидом или серией его заместителей (самоповреждение, суицидальная попытка и т.п.). В пользу своего мнения можем привести довод, что в американском диагностическом и статистическом руководстве по психическим расстройствам DSM-V (США) суицид и несуицидальное самоповреждающее поведение размещены в разделе III, в который относят «рекомендуемые для дальнейшего изучения расстройства, исследование которых имеет высокий научный потенциал» [49]. Предполагается, что по мере накопления фактологического материала и выяснения патогенеза заболеваний, размещённых в разделе III DSM-V, они будут выделены в самостоятельные нозологические единицы и представлены в других разделах этой классификации. Напомним, of the formation of morphological sex differences in the sense that primary sexual differentiation ultimately leads to the creation of gene networks differing in the genetic composition that form the corresponding behavioral and mental stereotypes, including pathological ones. That is, the primary changes in the expression of embryonic genes, which ensure the formation of primary sexual characteristics, subsequently cause the expression and formation of different gene networks in the sexes. If genes with any polymorphisms enter these networks, their expression changes the final result of the entire network with the implementation of an evolutionarily losing or biologically indifferent phenotype. Accordingly, in phylogeny, genes could be developed that impede the implementation of an evolutionarily losing individual phenotype, if such a phenotype threatens the existence of the species as a whole. Maternal suppressor genes of the genome passed on to the offspring by the male, realizing a suppressive effect if the father's genome contains genes whose expression threatens the death of offspring, have been found to date, at least in lepidoptera $[46,49]$.

It is known that more than $50 \%$ of completed suicides were committed by people without known mental illness. Therefore, it was suggested that suicidality should be considered as a special psychiatric diagnosis, with its symptoms and splitting pathological processes [48]. This goes along with our idea that the suicidal phenotype should be considered as a multifactorial state ending in suicide or a series of its substitutes (self-harm, suicidal attempt, etc.). To support our opinion, we can argue that in the American Diagnostic and Statistical Manual of Mental Disorders DSM-V (USA), suicide and non-suicidal self-injurious behavior are placed in section III, which includes "disorders recommended for further study, the study of which has a high scientific potential" [49]. It is assumed that as the accumulation of factual material and the clarification of the pathogenesis of the diseases listed in Section III of the DSM-V, they will be separated into independent nosological units and presented in other sections of this classification. Recall that the multifactorial group includes diseases whose pathogenesis is associated with a primary defect of several genes, the network interaction of which, 
что в группу мультифакториальных относят заболевания патогенез которых связан с первичным дефектом нескольких генов, сетевое взаимодействие которых под воздействием внешних факторов среды реализуется в клинический фенотип заболевания. Поэтому суицидальный фенотип может рассматриваться как мультифакториальное заболевание, крайним исходом которого является смерть в результате совершения суицида, а не функционального возрастного истощения каких-либо систем органов, как при известных мультифакториальных заболеваниях с доказанным патогенезом.

Проведённый анализ работ, опубликованных за последние 20 лет, посвящённых исследованию связи генома с гендерными различиями суицидального фенотипа, позволяет сделать следующие выводы :

1) формирование суицидального фенотипа у мужчин и женщин связано со значительно различающихся составом паттернов генов, локализованных как на половых, так и соматических хромосомах;

2) по-видимому, существуют полоспецифичные паттерны генетических полиморфизмов, совокупная активность которых завершается суицидом в определённые возрастные периоды, что определяет дожитие их носителей до возраста совершения суицида.

\section{Литература / References:}

1. Розанов В.А. К вопросу о гендерном парадоксе в суицидологии - современный контекст. Суицидология. 2021; 12 (1): 80-108. [Rozanov V.A. On the gender paradox in suicidology - a contemporary context. Suicidology. 2021; 12 (1): 80108.] (In Russ / Engl) DOI: 10.32878/suiciderus.20-12-01(42)80-108

2. Barrigon M.L., Cegla-Schvartzman F. Sex, Gender, and Suicidal Behavior. Curr. Top. Behav. Neurosci. 2020; 46: 89-115. DOI: 10.1007/7854_2020_165

3. Prevention suicide: a global imperative. Geneva: World Health Organizations. 2014. 102 p.

4. Suicide in the world: Global Health Estimates. Geneva: World Health Organizations. 2019. 30 p.

5. Евсеев А.А. Статистический анализ тенденций и факторов суицидального поведения. Экономика, Статистика и Информатика. 2012; 6 (2): 86-90. [Evseev A.A. Statistical analysis of tendencies and factors of suicidal behavior. Economics, Statistics and Informatics. 2012; 6 (2): 86-90.] (In Russ)

6. Adams N., Hitomi M., Moody C. Varied Reports of Adult Transgender Suicidality: Synthesizing and Describing the PeerReviewed and Gray Literature. Transgend Health. 2017; 2 (1): 60-75. DOI: $10.1089 / \operatorname{trgh} .2016 .0036$

7. Blosnich J.R., Brown G.R., Shipherd Phd J.C., Kauth M., Piegari R.I., Bossarte R.M. Prevalence of gender identity disorder and suicide risk among transgender veterans utilizing veterans' health administration care. Am. J. Public. Health. 2013; 103 (10): e2732. DOI: 10.2105/AJPH.2013.301507

8. Global Health Observatory data repository. Suicide rate estimates, age-standardized Estimates by country. https://apps.who.int/gho/data/node.main.MHSUICIDEASDR?lan $\mathrm{g}=\mathrm{en}]$

9. Ritchie H., Roser M., Ortiz-Ospina E. Suicide. Published online at OurWorldInData.org. 2015. Retrieved from: 'https://ourworldindata.org/suicide' [Online Resource] under the influence of external environmental factors, is realized in the clinical phenotype of the disease. Therefore, the suicidal phenotype can be considered as a multifactorial disease, the extreme outcome of which is death as a result of committing suicide, rather than functional age-related depletion of any organ systems, as in known multifactorial diseases with proven pathogenesis.

The analysis of works published over the past 20 years devoted to the study of the relationship of the genome with gender differences in the suicidal phenotype allows us to draw the following conclusions:

1) the formation of a suicidal phenotype in men and women is associated with a significantly different composition of gene patterns localized on both sex and somatic chromosomes;

2) apparently, there are sex-specific patterns of genetic polymorphisms, the aggregate activity of which ends in suicide at certain age periods, which determines the survival of their carriers to the age of committing suicide.

10. Sokolowski M., Wasserman J., Wasserman D. An overview of the neurobiology of suicidal behaviors as one meta-system. Mol. Psychiatry. 2015; $20 \quad$ (1): 56-71. DOI: $10.1038 / \mathrm{mp} .2014 .101$

11. Fiori L.M., Mechawar N., Turecki G. Identification and characterization of spermidine/spermine N1-acetyltransferase promoter variants in suicide completers. Biol Psychiatry. 2009; 66 (5): 460467. DOI: 10.1016/j.biopsych.2009.04.002

12. Fiori L.M., Zouk H., Himmelman C., Turecki G. X chromosome and suicide. Mol Psychiatry. 2011; 16 (2): 216-226. DOI: 10.1038/mp.2009.132

13. Molina-Guzman G., González-Castro T.B., Hernández Díaz Y., Tovilla-Zárate C.A., Juárez-Rojop I.E., Guzmán-Priego C.G., Genis A., Pool García S., López-Narvaez M.L., Rodriguez-Perez J.M. Gender differences in the association between HTR2C gene variants and suicidal behavior in a Mexican population: a casecontrol study. Neuropsychiatr. Dis. Treat. 2017; 13: 559-566. DOI: $10.2147 /$ NDT.S122024

14. Videtic A., Peternelj T.T., Zupanc T., Balazic J., Komel R. Promoter and functional polymorphisms of HTR2C and suicide victims. Genes Brain Behav. 2009; 8 (5): 541-545. DOI: 10.1111/j.1601-183X.2009.00505.x

15. Guo X., Dai X., Zhou T., Wang H., Ni J., Xue J., Wang X. Mosaic loss of human Y chromosome: what, how and why. Hum. Genet. 2020; 139 (4): 421-446. DOI: 10.1007/s00439-02002114-w

16. Kimura A., Hishimoto A., Otsuka I., Okazaki S., Boku S., Horai T., Izumi T., Takahashi M., Ueno Y., Shirakawa O., Sora I. Loss of chromosome $\mathrm{Y}$ in blood, but not in brain, of suicide completers. PLoS One. 2018; 13 (1): e0190667. DOI: 10.1371/journal.pone.0190667

17. Guo X., Dai X., Zhou T., Wang H., Ni J., Xue J., Wang X. Mosaic loss of human Y chromosome: what, how and why. Hum. Genet. 2020; 139 (4): 421-446. DOI: 10.1007/s00439020-02114-w 
18. Marzais B., Vorsanova S.G., Roizes G., Yurov Y.B. Analysis of alphoid DNA variation and kinetochore size in human chromosome 21: evidence against pathological significance of alphoid satellite DNA diminutions. Tsitol. Genet. 1999; 33 (1): 25-31.

19. Fountoulakis K.N., Gonda X. Ancestry and different rates of suicide and homicide in European countries: A study with population-level data. J. Affect. Disord. 2018; 232: 152-162. DOI: 10.1016/j.jad.2018.02.030

20. Hodes G.E., Pfau M.L., Purushothaman I., Ahn H.F., Golden S.A., Christoffel D.J., Magida J., Brancato A., Takahashi A., Flanigan M.E., Ménard C., Aleyasin H., Koo J.W., Lorsch Z.S., Feng J., Heshmati M., Wang M., Turecki G., Neve R., Zhang B., Shen L., Nestler E.J., Russo S.J. Sex differences in nucleus accumbens transcriptome profiles associated with susceptibility versus resilience to subchronic variable stress. J. Neurosci. 2015; 35 (50): 16362-16376. DOI: 10.1523/JNEUROSCI.139215.2015

21. Cabrera-Mendoza B., Fresno C., Monroy-Jaramillo N., Fries G.R., Walss-Bass C., Glahn D.C., Ostrosky-Wegman P., Mendoza-Morales R.C., García-Dolores F., Díaz-Otañez C.E., GonzálezSáenz E.E., Genis-Mendoza A.D., Martínez-Magaña J.J., Romero-Pimentel A.L., Flores G., Vázquez-Roque R.A., Nicolini H. Sex differences in brain gene expression among suicide completers. J. Affect. Disord. 2020; 267: 67-77. DOI: 10.1016/j.jad.2020.01.167

22. Schenkel L.C., Segal J., Becker J.A., Manfro G.G., Bianchin M.M., Leistner-Segal S. The BDNF Val66Met polymorphism is an independent risk factor for high lethality in suicide attempts of depressed patients. Prog. Neuropsychopharmacol. Biol. Psychiatry. 2010; 34 (6): 940-944. DOI: 10.1016/j.pnpbp.2010.04.023

23. Paska A.V., Zupanc T., Pregelj P. The role of brain-derived neurotrophic factor in the pathophysiology of suicidal behavior. Psychiatr. Danub. 2013; 25 Suppl 2: 341-344.

24. Gaynor S.C., Monson E.T., Gaine M.E., Chimenti M.S., Reichman R.D., Parsons M., Oonthonpan L., Zandi P.P., Potash J.B., Willour V.L. Male-specific association of the $2 \mathrm{p} 25$ region with suicide attempt in bipolar disorder. J. Psychiatr. Res. 2020; 121: 151-158. DOI: 10.1016/j.jpsychires.2019.11.009

25. Wendt F.R., Pathak G.A., Levey D.F., Nuñez Y.Z., Overstreet C., Tyrrell C., Adhikari K., De Angelis F., Tylee D.S., Goswami A., Krystal J.H., Abdallah C.G., Stein M.B., Kranzler H.R., Gelernter J., Polimanti R. Sex-stratified gene-by-environment genome-wide interaction study of trauma, posttraumatic-stress, and suicidality. Neurobiol. $\quad$ Stress. 2021; 14: 100309. DOI: 10.1016/j.ynstr.2021.100309

26. Powers B., Joyce C., Kleinman J.E., Hyde T.M., Ajilore O., Leow A., Sodhi M.S. Sex differences in the transcription of glutamate transporters in major depression and suicide. J. Affect. Disord. 2020; 277: 244-252. DOI: 10.1016/j.jad.2020.07.055

27. Baca-García E., Vaquero C., Diaz-Sastre C., Saiz-Ruiz J., Fernández-Piqueras J., de Leon J. A gender-specific association between the serotonin transporter gene and suicide attempts. Neuropsychopharmacology. 2002; $26 \quad$ (5): 692-695. DOI: 10.1016/S0893-133X(01)00394-3

28. Baca-Garcia E., Vaquero C., Diaz-Sastre C., Ceverino A., SaizRuiz J., Fernández-Piquera J., de Leon J. A pilot study on a genehormone interaction in female suicide attempts. Eur. Arch. Psychiatry Clin. Neurosci. 2003. Dec; 253 (6): 281-285. DOI: 10.1007/s00406-003-0441-6

29. Lin P.Y., Tsai G. Association between serotonin transporter gene promoter polymorphism and suicide: results of a meta-analysis. Biol. Psychiatry. 2004; 55 (10): 1023-1030. DOI: 10.1016/j.biopsych.2004.02.006

30. Gaysina D., Zainullina A., Gabdulhakov R., Khusnutdinova E. The serotonin transporter gene: polymorphism and haplotype analysis in Russian suicide attempters. Neuropsychobiology. 2006; 54 (1): 70-74. DOI: 10.1159/000096041

31. Azenha D., Alves M., Matos R., Santa J.F., Silva B., Cordeiro C., Vieira D.N., Ambrósio A.M. Male specific association between the 5-HTR6 gene 267C/T SNP and suicide in the Portuguese population. Neurosci Lett. 2009; 466 (3): 128-130. DOI: 10.1016/j.neulet.2009.09.040

32. Lachman H.M., Papolos D.F., Saito T., Yu Y.M., Szumlanski C.L., Weinshilboum R.M. Human catechol-O-methyltransferase pharmacogenetics: description of a functional polymorphism and its potential application to neuropsychiatric disorders. Pharmacogenetics. 1996; 6: 243-250.

33. Ono H., Shirakawa O., Nushida H., Ueno Y., Maeda K. Association between catechol-O-methyltransferase functional polymorphism and male suicide completers. Neuropsychopharmacology. 2004; 29 (7): 1374-1377. DOI: 0.1038/sj.npp.1300470

34. Lee H.Y., Kim Y.K. Gender effect of catechol-Omethyltransferase Val158Met polymorphism on suicidal behavior. Neuropsychobiology. 2011; 63 (3): 177-182. DOI: $10.1159 / 000317847$

35. Du L., Faludi G., Palkovits M., Sotonyi P., Bakish D., Hrdina P.D. High activity-related allele of MAO-A gene associated with depressed suicide in males. Neuroreport. 2002; 13 (9): 1195 1198. DOI: 10.1097/00001756-200207020-00025

36. Pivac N., Pregelj P., Nikolac M., Zupanc T., Nedic G., Muck Seler D., Videtic Paska A. The association between catechol-Omethyl-transferase Val108/158Met polymorphism and suicide. Genes Brain Behav. 2011; 10 (5): 565-569. DOI: 10.1111/j.1601183X.2011.00695.X

37. Lee H.Y., Kim Y.K. Gender effect of catechol-Omethyltransferase Val158Met polymorphism on suicidal behavior. Neuropsychobiology. 2011; 63 (3): 177-182. DOI: 10.1159/000317847

38. Rahikainen A.L., Palo J.U., Haukka J., Sajantila A. Post-mortem analysis of suicide victims shows ABCB1 haplotype 1236T2677T-3435T as a candidate predisposing factor behind adverse drug reactions in females. Pharmacogenet. Genomics. 2018; 28 (4): 99-106. DOI: 10.1097/FPC.0000000000000328

39. Boiso Moreno S., Zackrisson A.L., Jakobsen Falk I., Karlsson L., Carlsson B., Tillmar A., Kugelberg F.C., Ahlner J., Hägg S., Gréen $\mathrm{H}$. ABCB1 gene polymorphisms are associated with suicide in forensic autopsies. Pharmacogenet. Genomics. 2013; 23 (9): 463-469. DOI: 10.1097/FPC.0b013e328363a9bf

40. Peñas-Lledó E., Guillaume S., Delgado A., Naranjo M.E., Jaussent I., LLerena A., Courtet P. ABCB1 gene polymorphisms and violent suicide attempt among survivors. J. Psychiatr. Res. 2015; 61: 52-6. DOI: 10.1016/j.jpsychires.2014.12.005

41. Hirata T., Otsuka I., Okazaki S., Mouri K., Horai T., Boku S., Takahashi M., Ueno Y., Sora I., Shirakawa O., Hishimoto A. Major depressive disorder-associated SIRT1 locus affects the risk for suicide in women after middle age. Psychiatry Res. 2019; 278: 141-145. DOI: 10.1016/j.psychres.2019.06.002

42. Harris C., Cloutier M., Trotter M., Hinten M., Gayen S., Du Z., Xie W., Kalantry S. Conversion of random X-inactivation to imprinted X-inactivation by maternal PRC2. Elife. 2019; 8: e44258. DOI: $10.7554 /$ eLife. 44258

43. Грабарь В.А., Казарьянц А.Э. Функциональная аннотация генов, локализованных на Y-хромосоме человека [Электронный ресурс]. Живые и биокосные системы. 2017; 22: URL: http://www.jbks.ru/archive/issue-22/aricle-5 [Grabar V.A., Kazaryants A.E. Functional annotation of genes localized on the Yhuman chromosome [Electronic resource]. Living and bioinert systems. 2017; 22: URL: http://www.jbks.ru/archive/issue22/aricle-5] (In Russ)

44. 400011 Acetylserotonin Methyltransferase-Like, Y-Linked. Retrieved from: https://omim.org/entry/400011?search=ASMTL\%20gene\&highli ght $=$ asmtl\%20gene [Online Resource]

45. Valdés-Tovar M., Estrada-Reyes R., Solís-Chagoyán H., Argueta J., Dorantes-Barrón A.M., Quero-Chávez D., Cruz-Garduño R., Cercós M.G., Trueta C., Oikawa-Sala J., Dubocovich M.L., Benítez-King G. Circadian modulation of neuroplasticity by melatonin: a target in the treatment of depression. Br. J. Pharmacol. 2018; 175 (16): 3200-3208. DOI: 10.1111/bph.14197 
46. Ross L., Shuker D.M., Pen I. The evolution and suppression of male suicide under paternal genome elimination. Evolution. 2011; 65 (2): 554-563. DOI: 10.1111/j.1558-5646.2010.01148.x

47. de la Filia A.G., Mongue A.J., Dorrens J., Lemon H., Laetsch D.R., Ross L. Males That Silence Their Father's Genes: Genomic Imprinting of a Complete Haploid Genome. Mol. Biol. Evol. 2021; msab052. DOI: 10.1093/molbev/msab052
48. Harmer B., Lee S., Duong T.V.H., Saadabadi A. Suicidal Ideation. 2020. In: StatPearls [Internet]. Treasure Island (FL): StatPearls Publishing; 2021.

49. Diagnostic and Statistical Manual of Mental Disorders, Fifth Edition. Arlington, VA, American Psychiatric Association, 2013. 947 p.

\title{
SUICIDAL BEHAVIOR: THE GENETIC ASPECT OF THE GENDER PARADOX
}

\author{
V.A. Kozlov, S.P. Sapozhnikov, \\ A.V. Golenkov
}

I.N. Ulyanov Chuvash State University, Cheboksary, Russia; pooh12@yandex.ru

\section{Abstract:}

The aim of this work is to systematize and interpret freely available, scattered, previously established data on the association of frequencies of suicides committed with gender (sex) genetic differences, the final result of which is the formation of an understanding of the various patterns of genes that form the suicidal phenotype in men and women by at least two different genetically realizable ways. The article deals with the issues of biological reasons for the formation of a suicidal phenotype as a consequence of the genetic program implemented as a result of the interaction of the pattern of polymorphic genes. As a result of calculating the gender suicidality rate (GSR - the quotient of dividing the relative rates of suicide rates in men by the rates of suicides in women, obtained according to WHO data as of 2019), it was concluded that the GSR value is generally constant and does not depend on climatic, geographic, economic, social and other external factors, which means it is determined by the humanity genetic background. We analyzed the literature data on the genetic differences in suicides of men and women obtained from the pubmed.ncbi.nlm.nih.gov database published during about a 20-year period, excluding works where suicides or suicidal attempts were committed due to severe mental disorders, either individual addictions, or in connection with acts of violence. The collected information allowed us to bring together two gene patterns that form the suicidal phenotype in men and women, respectively. Most of the genes associated with suicides in men are predominantly localized on the short arm of chromosome $\mathrm{X}$ and chromosome 22, as well as on chromosomes 1, 2, 5, 7, 11, 19. In addition, suicides in men are associated with age-related aberrations of early loss of the Y chromosome by blood cells. In women, genes localized on chromosomes 7, 10, 11, 17 and the HTR2C gene locus Xq23 are associated with suicides. There must also be a third non-sex pattern of genes associated with suicide. It is concluded that 1) there are sex-specific patterns of genetic polymorphisms, the total activity of which ends in suicide at certain age periods, which determines the survival of their carriers to the age of committing suicide; 2) the carriage of such patterns in the genome can be regarded as a multifactorial condition, the outcome of which is death as a result of committing suicide, and not functional age-related depletion of any organ systems.

Key words: suicide, gender paradox, genes associated with suicide patterns, gender suicidality rate

Вкмад авторов:

B.А. Козлов: дизайн структуры статьи, сбор материала и перевод публикаций по теме статьи, написание текста рукописи;

С.П. Сапожников: сбор материала, написание и редактирование текста рукописи;

А.В. Голенков: сбор материала, написание и редактирование текста рукописи.

Authors' contributions:

V.A. Kozlov: design of the structure of the article, collection of material and translation of publications on the topic of the article, writing of the text of the manuscript;

S.P. Sapozhnikov: collection of material, writing and editing of the text of the manuscript;

A.V. Golenkov: $\quad$ collection of material, writing and editing of the text of the manuscript.

Финансирование: Данное исследование не имело финансовой поддержки.

Financing: The study was performed without external funding.

Конфмикт интересов: Авторы заявляют об отсутствии конфмикта интересов.

Conflict of interest: The authors declare no conflict of interest.

Статья поступима / Article received: 15.03.2021. Принята к публикации / Accepted for publication: 06.07.2021.

Для цитирования: Козлов В.А., Сапожников С.П., Голенков А.В. Суицидальное поведение: генетический аспект гендерного парадокса. Суицицология. 2021; 12 (2): 31-50. doi.org/10.32878/suiciderus.21-12-02(43)-31-50

For citation: $\quad$ Kozlov V.A., Sapozhnikov S.P., Golenkov A.V. Suicidal behavior: the genetic aspect of the gender paradox. Suicidology. 2021; 12 (2): 31-50. doi.org/10.32878/suiciderus.21-12-02(43)-31-50. (In Russ / Engl) 